\title{
Ovarian sex steroid receptors and sex hormones in androgenized rats
}

\author{
Vinícius Augusto Simão ${ }^{1}$, Luiz Gustavo de Almeida Chuffa ${ }^{2}$ and \\ Isabel Cristina Cherici Camargo ${ }^{1}$ \\ ${ }^{1}$ Universidade Estadual Paulista - UNESP, Faculdade de Ciências e Letras, Departamento de Ciências Biológicas. \\ Assis, São Paulo, Brazil and ${ }^{2}$ Universidade Estadual Paulista - UNESP, Instituto de Biociências, \\ Departamento de Anatomia. Botucatu, São Paulo, Brazil \\ Correspondence should be addressed to I C C Camargo; Email: camargo@assis.unesp.br
}

\begin{abstract}
This study evaluated for the first time the effects of different doses of the anabolic steroid nandrolone decanoate (ND) on the expression of ovarian steroid receptors (AR, ER- $\alpha$ (ESR1) and ER- $\beta$ (ESR2)) and related sex hormones after treatment and recovery periods in adult rats. The animals were injected subcutaneously with doses of ND (1.87, 3.75, $7.5 \mathrm{or} 15 \mathrm{mg} / \mathrm{kg} \mathrm{b.w.)} \mathrm{or} \mathrm{mineral} \mathrm{oil}$ (control group) for 15 days, and the experimental groups were divided into three periods of evaluation: (a) ND treatment for 15 days, (b) ND treatment and recovery for a period of 30 days and (c) ND treatment and recovery for a period of 60 days. Estrous cycle was monitored daily. At the end of each period, rats were killed for collection of blood and ovaries. Persistent diestrus occurred in all rats during ND treatment and after 30-day recovery. The highest dose of ND was able to maintain all rats arrested at diestrus until 60-day recovery. The expression of steroid receptors varied in a dose- and period-dependent manner, having a more pronounced response with the dose of $15 \mathrm{mg} \mathrm{ND} / \mathrm{kg}$. ND treatment increased serum levels of testosterone, $17 \beta$-estradiol and dihydrotestosterone, especially at the highest doses of 7.5 and $15 \mathrm{mg} \mathrm{ND/kg}$. No change was observed in the levels of follicle-stimulating hormone (FSH), whereas levels of the luteinizing hormone (LH) varied according to the dose and period. In conclusion, the ovarian sex steroid receptors and sex hormones were restored only at lower doses of ND and after a longer period of recovery.

Reproduction (2016) $\mathbf{1 5 2}$ 545-559
\end{abstract}

\section{Introduction}

Anabolic androgenic steroids (AASs) are synthetic hormones derived from testosterone and developed for the therapeutic treatment of chronic diseases associated with the catabolic state of patient, immunosuppression, chronic obstructive pulmonary disease and hepatic or renal failure. They are also used for postmenopausal hormone replacement therapy and in cases of agerelated sarcopenia (Evans 2004, Arlt 2006, Kicman 2008). Nandrolone decanoate (ND) is an injectable anabolic steroid used mostly by athletes and nonathletes (Boff 2010). Although their prescription and marketing are under control in different countries, ND is used indiscriminately by humans to increase muscle mass and strength in a short period (Iriart et al. 2009). These substances are generally administered in supraphysiological doses that can reach up to 100 times the therapeutic dose of androgenic replacement (Clark \& Fast 1996).

Over the past decade, AAS use by women increased significantly (Thiblin \& Petersson 2004), and its adverse effects include deepening of the voice, growth of body hair, atrophy of the breasts, menstrual irregularities and clitoris hypertrophy (Maravelias et al. 2005, Kicman 2008). Studies using animals showed that ND causes changes in the estrous cycle (Gerez et al. 2005, Camargo et al. 2009a, Chuffa et al. 2011c), suppresses the reproductive capacity (Camargo et al. 2009b, 2014, Belardin et al. 2014), and causes changes in the ovarian and uterine histopathology (Gerez et al. 2005, Camargo et al. 2009a, Chuffa et al. 2011c, Camargo et al. 2014), which may have dose and time-dependent effect (Belardin et al. 2014, Simão et al. 2015).

Sex steroid receptors are essential in orchestrating a number of ovarian functions, such as folliculogenesis, luteogenesis, steroidogenesis and ovulation, as well as in the maintenance of fertility. Disruption in the expression of steroid receptors can negatively affect these processes, and AASs are expected to be a critical factor in hormonal deregulation. AAS and its metabolites exert their functions after binding to the androgen receptor (AR); otherwise, it can be aromatized into estrogens by the aromatase cytochrome P450. Estrogens, in turn, regulate a number of activities through the estrogen receptors termed ER- $\alpha$ and ER- $\beta$ (Clark et al. 2006, Drummond \& Fuller 2012). The signaling pathways mediated by AR 
and ER are extremely important to guide the action of steroids in reproductive tissue (e.g. ovarian tissue), and any alteration at the hormone-receptor interface may cause tissue damage.

Undoubtedly, folliculogenesis is a complex mechanism that involves the action of several hormones, such as follicle-stimulating hormone ( $\mathrm{FSH})$, luteinizing hormone $(\mathrm{LH})$, $17 \beta$-estradiol $\left(\mathrm{E}_{2}\right)$, progesterone $\left(\mathrm{P}_{4}\right)$, testosterone (T) and dihydrotestosterone (DHT) (Lima-Verde et al. 2011), in addition to numerous growth factors (Rosa e Silva et al. 2006) and thyroid hormones (Serakides et al. 2001). According to Ehrmann (2005), the increase in androgens is associated with pathologies in the female reproductive tract, such as polycystic ovary syndrome (PCOS). In PCOS, the ovaries contain multiple follicular cysts and absence of corpora lutea. Recently, we showed a similar condition in the ovaries of rats treated with ND (Camargo et al. 2014, Simão et al. 2015). To strengthen our findings, it has been reported that exogenous androgens produce inhibitory or stimulating effects on different stages of follicular development (Wang \& Chang 2004, Walters et al. 2008). However, whether the effects are mediated directly by AR or indirectly through the conversion of androgen into estrogens, thus acting via $E_{2}$-ER signaling, remain a matter of debate.

Although extensive studies are conducted to investigate the effects of anabolic steroids in the reproduction, little information is focused on the reversibility of their side effects. We recently reported that lower ND doses and longer period of post-treatment recovery efficiently restored estrous cycle, ovarian and uterine activities, and even fertility in rats (Belardin et al. 2014, Simão et al. 2015). These findings are important to deeply understand which mechanism(s) may be responsible in mitigating the ND-induced reproductive pathologies in females. To date, no study has focused on the effects of ND on sex hormonal regulation and ovarian steroid receptors. Therefore, this study aimed to evaluate the effects of different doses of ND on the expression of ovarian AR, ER- $\alpha, E R-\beta$ and aromatase CYP450, and serum levels of FSH, LH, $\mathrm{E}_{2}, \mathrm{P}_{4}, \mathrm{~T}$ and $\mathrm{DHT}$ in rats, after treatment and 30 and 60 days of recovery.

\section{Materials and methods}

\section{Animals}

Ninety adult female Wistar rats (Rattus norvegicus albinus), 12 weeks old, weighing approximately $250 \mathrm{~g}$, were obtained from the Universidade Estadual Paulista (UNESPBotucatu, São Paulo, Brazil) and kept in appropriate cages at the Central Biotherium of the Faculty of Sciences and Letters (UNESP- Assis, São Paulo, Brazil). The females were housed in polypropylene cages $(43 \mathrm{~cm} \times 30 \mathrm{~cm} \times 15 \mathrm{~cm})$ with laboratory-grade pine shavings as bedding and maintained under controlled room temperature (RT, $23 \pm 1^{\circ} \mathrm{C}$ ) and lighting conditions (12L, 12D photoperiod, 200 lux, lights switched on at 07:00 h). Water and commercial diet (Nuvital, Colombo, Paraná, Brazil) were provided ad libitum. The experimental protocol followed the ethical principles in animal research adopted by the Brazilian College of Animal Experimentation and was approved by the Ethical Committee for Animals Use (Permit number: 005/2011; 31 August).

\section{Drug}

Nandrolone decanoate (17 $\beta$-hydroxy-19-nor-4-androstene-3one; Deca Durabolin) was purchased from Schering-Plough Laboratory (São Paulo, Brazil). ND is an injectable solution, containing $50 \mathrm{mg}$ of the androgen, available as an oily solution (Marqueti et al. 2010).
A 1

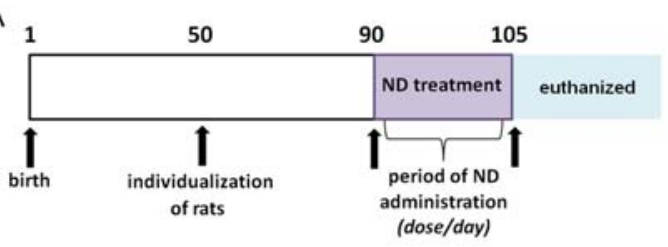

B 1

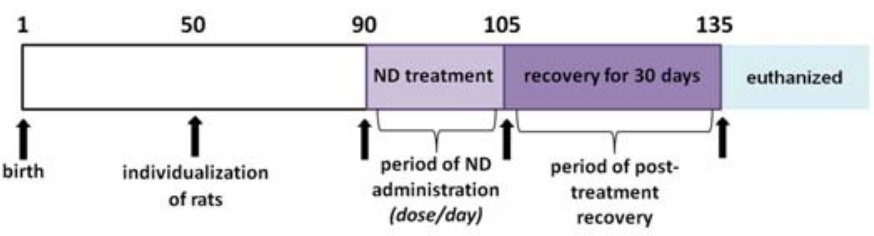

$C_{1}$

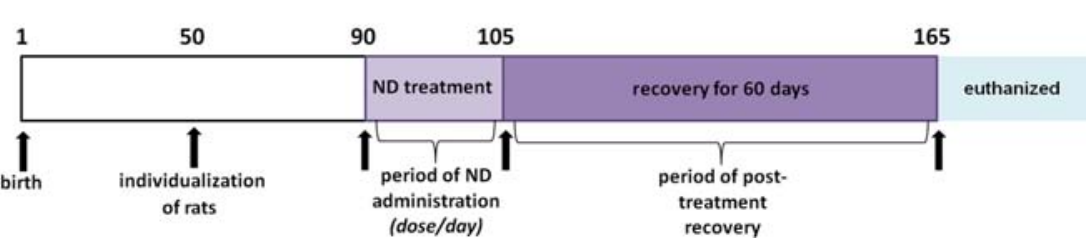

Figure 1 Chronological experimental design in days. (A) At 90 days, six rats per dose level $(1.87,3.75,7.5$ and $15 \mathrm{mg} \mathrm{ND} / \mathrm{kg})$ were killed at the end of the treatment period. (B) Six rats per dose level $(1.87,3.75,7.5$ and $15 \mathrm{mg}$ $\mathrm{ND} / \mathrm{kg}$ ) received the treatment for 15 days and were maintained in the recovery period for 30 days (105-135-days-old), followed by killing. (C) Six rats per dose level $(1.87,3.75$, 7.5 and $15 \mathrm{mg} \mathrm{ND} / \mathrm{kg}$ ) received the treatment for 15 days and were maintained in the recovery period for 60 days (105-165-days-old), followed by killing. 
A

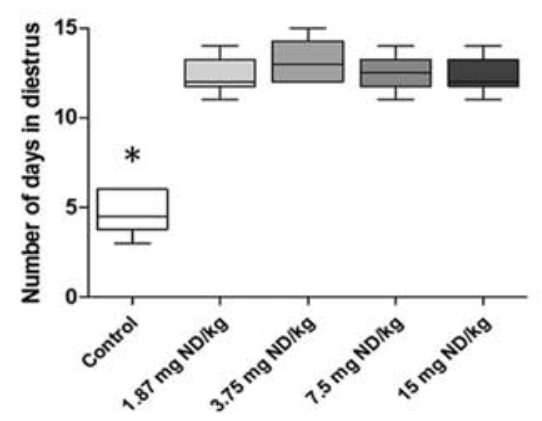

B

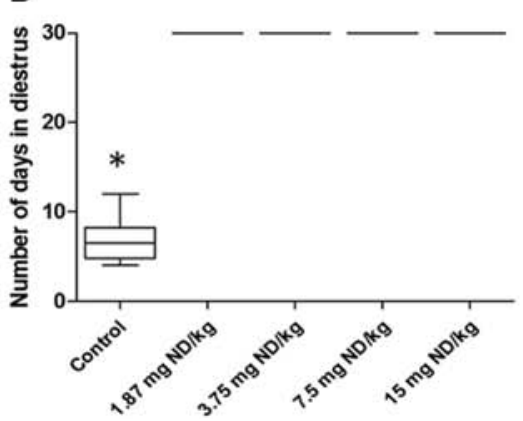

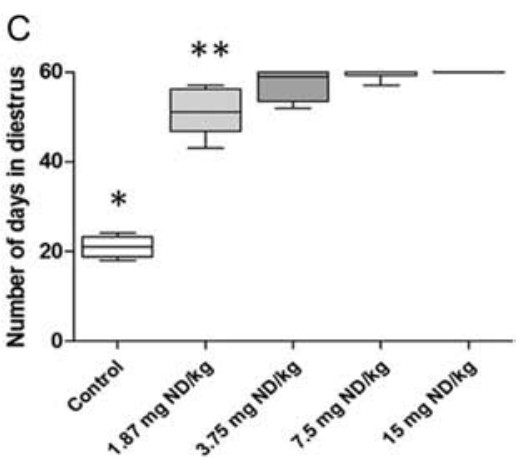

Figure 2 Number of diestrus (days) in animals treated with ND $(1.87,3.75,7.5$ and $15 \mathrm{mg} / \mathrm{kg}$ ) after the treatment period (A), 30-day recovery period (B) and 60-day recovery period (C) compared with the control animals displaying regular estrous cycle, and killed in diestrus. ${ }^{*} P<0.05$ vs all steroidal groups; ${ }^{* *} P<0.05$ vs groups treated at doses of $3.75,7.5$ and $15 \mathrm{mg} \mathrm{ND} / \mathrm{kg}$. Values expressed as the mean \pm S.E.M. ANOVA complemented by Tukey test.

\section{Experimental design}

Females with regular estrous cycle were weighed and randomly divided into five groups ( $n=18 /$ group): control (C), treated with an injection of $0.1 \mathrm{~mL}$ mineral oil for 15 consecutive days subcutaneously (s.c.), and ND-treated groups: received doses of $1.87,3.75,7.5$ and $15 \mathrm{mg} / \mathrm{kg}$ b.w., via sc, diluted in vehicle, for 15 consecutive days. The injections were administered by a single-daily injection in the same interval (12:30-13:00 h) to minimize the effects of manipulation on animal welfare.
Each experimental group was subdivided according to the three periods of study ( $n=6$ rats/group/period, Fig. $1 \mathrm{~A}$, $B$ and $C$ ): ND-treated animals for 15 days and killed at the end of treatment period (A) and ND-treated animals for 15 days, followed by a recovery period of 30 (B) or 60 (C) days, and killed at the end of each period. Due to the prolonged diestrus phase in ND-treated animals during experimentation, they were killed in this stage of the cycle including in the control group to keep the same criteria for comparison. After each period (15 days of treatment and 30 and 60 days of recovery), all animals were weighed

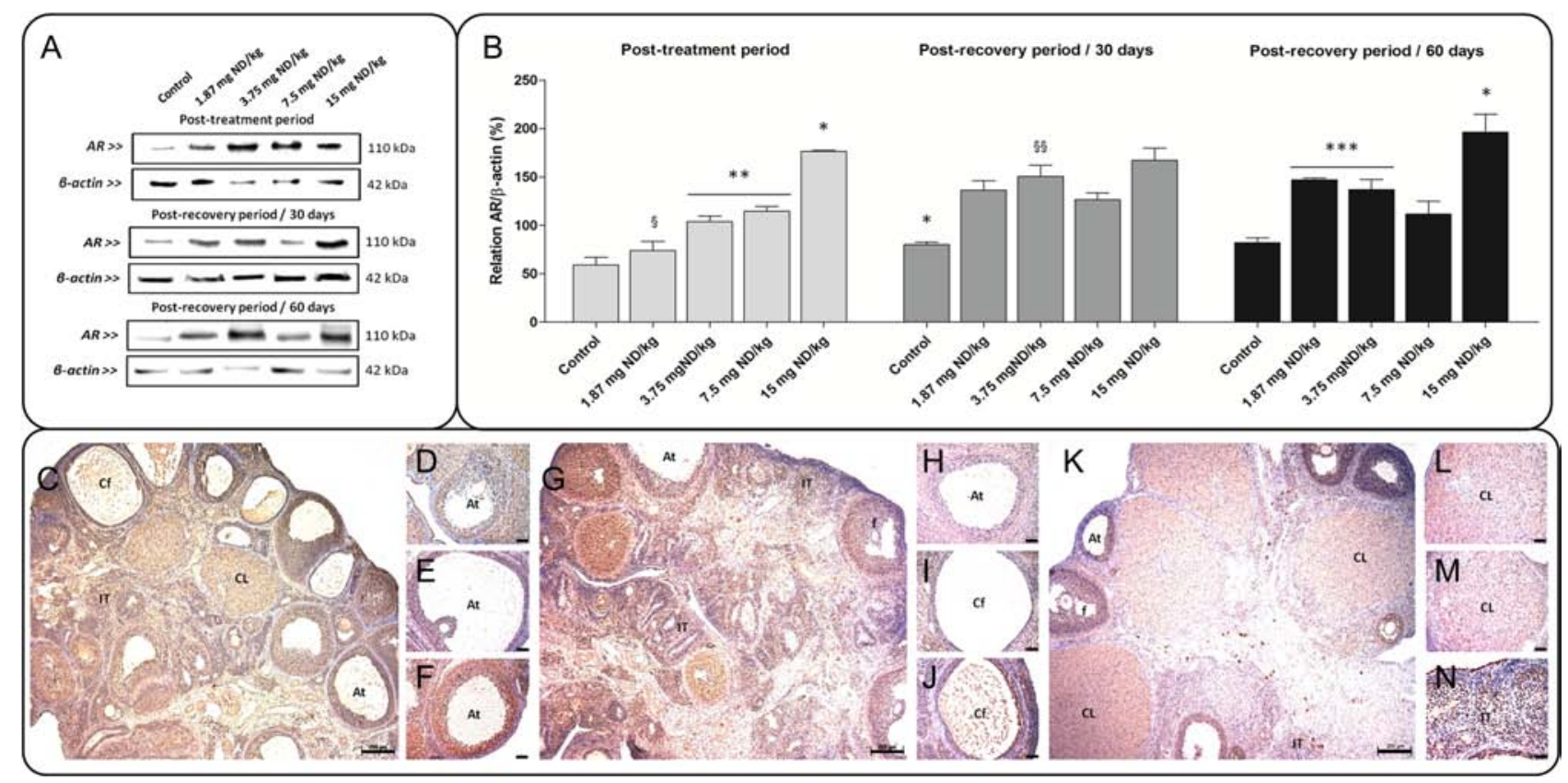

Figure 3 Western blot analysis and immunohistochemical localization of AR in the experimental groups after ND treatment and 30- and 60-day recovery. (A) Representation of the protein expression profiles $(70 \mu \mathrm{g})$ in pooled extracts of six samples/group. (B) The extracts obtained from the individual rats were used for densitometric analysis of AR levels followed by normalization of $\beta$-actin. ${ }^{*} P<0.05$ vs other groups; ${ }^{* *} P<0.05$ vs control group and $1.87 \mathrm{mg} \mathrm{ND} / \mathrm{kg}$; ${ }^{* * *} P<0.05$ vs control group. ${ }^{\circledR} P<0.05$ vs respective group in other experimental periods; ${ }^{\$} \$ P<0.05$ vs respective group in the treatment period. Immunoreactivity for AR in the control group (D, $H$ and $\left.L\right)$, and ND-treated groups at the doses of $1.87 \mathrm{mg} \mathrm{ND} / \mathrm{kg}$ (C, G and K); $3.75 \mathrm{mg} \mathrm{ND} / \mathrm{kg}$ (E and M); $7.5 \mathrm{mg} \mathrm{ND/kg} \mathrm{(I)} \mathrm{and} 15 \mathrm{mg} \mathrm{ND} / \mathrm{kg}(\mathrm{F}$, J and N) in the different periods of the study. $\mathrm{f}$ (healthy follicle); At (atretic follicle); Cf (cystic follicle); CL (corpora lutea); IT (interstitial tissue). Bar $=200 \mu \mathrm{m}(\mathrm{C}, \mathrm{G}$ and K) and $50 \mu \mathrm{m}(\mathrm{D}-\mathrm{F}, \mathrm{H}-\mathrm{J}$ and $\mathrm{L}-\mathrm{N})$. Negative control was used. Values expressed as the mean \pm S.E.M. ANOVA complemented by Tukey test. 
and killed using anesthetic saturation in $\mathrm{CO}_{2}$ followed by decapitation for further blood and ovarian tissue collection.

\section{Selection of dosages}

The highest doses of 7.5 and $15 \mathrm{mg} \mathrm{ND} / \mathrm{kg}$ were chosen based on previous studies in animals (Blasberg et al. 1997, Camargo et al. 2011, Mobini Far et al. 2007). These concentrations mimic the non-therapeutic doses of AAS (ranging from 200 to $3200 \mathrm{mg} /$ week; Evans 1997), used by athletes to improve performance. The lowest doses of 1.87 and $3.75 \mathrm{mg} \mathrm{ND} / \mathrm{kg}$ were chosen based on recommended doses for various treatments, such as osteoporosis (50 mg every 3-4 weeks; Geusens 1995), chronic renal failure (25-100 mg/week; Barton Pai et al. 2002) and rheumatoid arthritis (50 mg every 3 weeks; Bird et al. 1987), or even considered doses lower than that used for physiological replacement (ranging from 25 to $600 \mathrm{mg} /$ week; Bhasin et al. 2005). The allometric calculations for animal dosing were described previously by Belardin and coworkers (2014).

\section{Assessment of estrous cycle}

During the treatment and recovery periods, the estrous cycle was monitored daily by cytological examination (vaginal swabs, Marcondes et al. 2002, Chuffa et al. 2009, $2011 a, b)$. The time of collection was fixed at 09:00 h. Each slide containing cells detached from the vaginal epithelium was analyzed under a light microscope (Olympus CX31 RBSFA, Tokyo, Japan). The phases of the estrous cycle were identified according to the criteria described by Goldman and coworkers (2007).

\section{Immunohistochemistry}

The right ovaries were fixed in buffered $10 \%(\mathrm{v} / \mathrm{v})$ formalin (0.2 $\mathrm{MNaH}_{2} \mathrm{PO}_{4}, \quad 0.2 \mathrm{MNa}_{2} \mathrm{HPO}_{4}, \quad 37 \%$ formaldehyde LABIMPEX Ltda. Diadema, São Paulo, Brazil, pH 7.2) for $24 \mathrm{~h}$. Then, the tissue was dehydrated in ethanol solutions and clarified in xylene for inclusion in paraffin (ParaplastOxford Labware, St. Louis, MO, USA). The blocks were cut into $4 \mu \mathrm{m}$ thick sections on a microtome Leica RM2125 (Germany), and tissue sections were microwaved while they were immersed in sodium citrate buffer $0.01 \mathrm{M}, \mathrm{pH}$ 6.0 for antigen retrieval. After blocking the endogenous peroxidase, tissue was incubated with $3 \%$ bovine serum albumin (BSA, 3\%) for $1 \mathrm{~h}$ to prevent nonspecific binding. Subsequently, ovary sections were incubated in a humid chamber overnight at $4{ }^{\circ} \mathrm{C}$ with primary antibody AR (dilution 1:100, NB300-551, Novus Biologicals, Littleton, CO, USA), anti-receptor estrogen alpha (ER- $\alpha)$ (1:100 dilution, NB11056961, Novus Biologicals), anti-estrogen receptor beta (ER- $\beta$ ) (dilution $1 \mu \mathrm{g} / \mathrm{mL}$ NB120-3577, Novus Biologicals) and anti-aromatase CytP450 (1:100 dilution, NBP1-19697, Novus Biologicals). After reactions, the slides were washed in phosphate buffered saline $(\mathrm{pH} \mathrm{7.0)}$ ) and incubated with the secondary antibody (Anti-Mouse Polymer IgG or AntiRabbit - DAKO CYT) at RT for $1 \mathrm{~h}$. Finally, the slides were placed to react with the chromogen diaminobenzidine (Sigma) for $5 \mathrm{~min}$ and then the sections were counterstained

Table 1 Immunolocalization and intensity of AR in the ovaries of different experimental groups, after treatment and recovery periods.

\begin{tabular}{|c|c|c|c|c|c|}
\hline \multirow[b]{2}{*}{ Parameters } & \multicolumn{5}{|c|}{ Experimental groups ( $n=6 /$ group) } \\
\hline & Control & $1.87 \mathrm{mg} \mathrm{ND} / \mathrm{kg}$ & $3.75 \mathrm{mg} \mathrm{ND} / \mathrm{kg}$ & $7.5 \mathrm{mg} \mathrm{ND} / \mathrm{kg}$ & $15 \mathrm{mg} \mathrm{ND} / \mathrm{kg}$ \\
\hline \multicolumn{6}{|c|}{ Post-treatment period } \\
\hline Primordial follicles & +++ & +++ & ++ & $+++/++$ & ++ \\
\hline Primary follicles & $++/+$ & +++ & $++/+++$ & ++ & $++/+++$ \\
\hline Growing follicles & + & + & +++ & ++ & +++ \\
\hline Antral follicles & $++/+$ & $++^{\mathrm{C}}+{ }^{\mathrm{N}}$ & +++ & $+++^{\mathrm{C}}++^{\mathrm{N}}$ & +++ \\
\hline Atretic follicles & ++ & $+++^{\mathrm{C}}++^{\mathrm{N}}$ & +++ & $+++{ }^{\mathrm{C}}++^{\mathrm{N}}$ & $+++^{\mathrm{C}}++^{\mathrm{N}}$ \\
\hline Cystic follicles & $*$ & $+++^{\mathrm{C}}++^{\mathrm{N}}$ & $++^{\mathrm{C}}+++^{\mathrm{N}}$ & $+++/++^{N}$ & +++ \\
\hline Corpora lutea & $++/+++{ }^{C}$ & $+++/++^{\mathrm{C}}$ & $+/++^{\mathrm{C}}$ & $+++/++{ }^{\mathrm{C}}$ & $+++^{\mathrm{C}}$ \\
\hline Interstitial tissue & + & $+/++$ & $+/++$ & + & $+/++$ \\
\hline \multicolumn{6}{|c|}{ Post-recovery period/30 days } \\
\hline Primordial follicles & $++/+$ & + & $-1+$ & $-1+$ & $++/+++$ \\
\hline Primary follicles & $+/++$ & $++/+++$ & ++ & ++ & $++/+$ \\
\hline Growing follicles & + & ++ & ++ & $++/+++$ & ++ \\
\hline Antral follicles & $+/-$ & +++ & +++ & $+++/++$ & $+++/++$ \\
\hline Atretic follicles & + & $+++/++{ }^{C}$ & $+++/++^{N}$ & ++ & $+++^{\mathrm{C}}++^{\mathrm{N}}$ \\
\hline Cystic follicles & $*$ & ++ & ++ & ++ & $+++^{\mathrm{C}}++^{\mathrm{N}}$ \\
\hline Corpora lutea & $++^{\mathrm{C}}$ & $*$ & $+^{\mathrm{C}}$ & $+^{\mathrm{C}}$ & $++^{\mathrm{C}}$ \\
\hline Interstitial tissue & ++ & ++ & + & $+/++$ & + \\
\hline \multicolumn{6}{|c|}{ Post-recovery period/60 days } \\
\hline Primordial follicles & $++/+$ & ++ & ++ & $++/+$ & +++ \\
\hline Primary follicles & ++ & $++^{\mathrm{C}}+{ }^{\mathrm{N}}$ & $++^{\mathrm{C}}+{ }^{\mathrm{N}}$ & + & $+++^{\mathrm{C}}++^{\mathrm{N}}$ \\
\hline Growing follicles & $+++/++$ & $++^{\mathrm{C}}+{ }^{\mathrm{N}}$ & $++^{\mathrm{C}}+{ }^{\mathrm{N}}$ & ++ & $+++^{\mathrm{C}}++^{\mathrm{N}} /+^{\mathrm{N}}$ \\
\hline Antral follicles & +++ & $++^{\mathrm{C}}+{ }^{\mathrm{N}}$ & $++/+^{N}$ & $+++^{\mathrm{C}}++^{\mathrm{N}}$ & $+++^{\mathrm{C}}++^{\mathrm{N}}$ \\
\hline Atretic follicles & ++ & + & $++^{\mathrm{C}}+{ }^{\mathrm{N}}$ & $++^{\mathrm{C}}+{ }^{\mathrm{N}}$ & $++^{\mathrm{C}}+{ }^{\mathrm{N}}$ \\
\hline Cystic follicles & $*$ & + & $++^{\mathrm{C}}++^{\mathrm{N}}$ & $++^{\mathrm{C}}+{ }^{\mathrm{N}}$ & $++^{\mathrm{C}}+{ }^{\mathrm{N}}$ \\
\hline Corpora lutea & $++^{\mathrm{C}}$ & $+++^{\mathrm{C}}++^{\mathrm{N}} /+^{\mathrm{N}}$ & $+++^{\mathrm{C}}++^{\mathrm{N}}$ & $*$ & $*$ \\
\hline Interstitial tissue & ++ & ++ & ++ & $++^{\mathrm{C}}+{ }^{\mathrm{N}}$ & $++/+$ \\
\hline
\end{tabular}

Reactions were classified as strong $(+++)$, moderate $(++)$, low $(+)$ and absent $(-)$.

*Structure absent in the ovaries. ${ }^{\mathrm{C}, \mathrm{N}}$ Different staining intensities in the cytoplasm $(\mathrm{C})$ and nucleus $(\mathrm{N})$. 
with hematoxylin. Negative controls were obtained by omitting the primary antibody.

The results were analyzed under a Zeiss Axio Scope-A1 (Carl Zeiss) microscope using the following staining intensity levels: absent $(-)$, low $(+)$, moderate $(++)$ and strong $(+++)$. In cases in which the intensity of staining differed between the nucleus and the cytoplasm, the symbol $(\mathrm{N})$ or (C) was added in superscript, respectively, to each intensity. When necessary, a vertical bar (/) was used to indicate the variation in cell immunostaining regarding different animals in the same group. Digital images were captured using a light microscope (Axio Scope A1-coupled to a video camera AxioCam ICc3) and digitized by AxioVision software version 4.7.2 (Carl Zeiss).

\section{Identification of the follicles}

The identification of healthy follicle subtypes was based on the classification proposed by Pedersen and Peters (1968), as follows: small follicles (primordial and primary), which consists of a small oocyte with no follicular cell attached to its surface or not more than 20 follicular cells surrounding the oocyte; medium follicles (secondary and growing), which consist of several layers of follicular cells surrounding the oocyte (number of cells varying between 21 and 200); large follicles (tertiary, Graafian or preovulatory), characterized by a large oocyte, many layers of granulosa cells and a cavity 'antrum', representing the various stages of follicle growth.

The criterion for the identification of atretic follicles was based on the degree of regression of antral follicles, according to following morphological characteristics (Osman 1985): shrinkage of the granulosa wall and degenerative cellular changes, presence of nuclear fragments at the periphery of the antrum, degenerative oocyte surrounded by an envelope of degenerating cumulus cells or oocyte 'naked' in the antrum, granulosa wall with a distinct inner lining and macrophages usually present in the antrum. At least two characteristics were considered to classify a follicle as atretic.

The follicular cysts were identified according to the following morphological characteristics reported by Dixon and coworkers (2014): usually lined by one to four layers of cubical granulosa cells and no luteinization, thin wall lined by a single layer of flattened cells resting on a thin fibrous capsule, larger than a normal preovulatory follicle and degeneration of individual granulosa cells.

\section{Immunoblots and protein quantification}

After each treatment and recovery periods, the left ovaries were removed and frozen in liquid nitrogen and stored at $-80^{\circ}$. Tissues were homogenized using RIPA lysis buffer (Pierce Biotechnology) and protease inhibitor cocktail (Sigma Chemical Co.), using a homogenizer (Ultra IKA T10 basic,

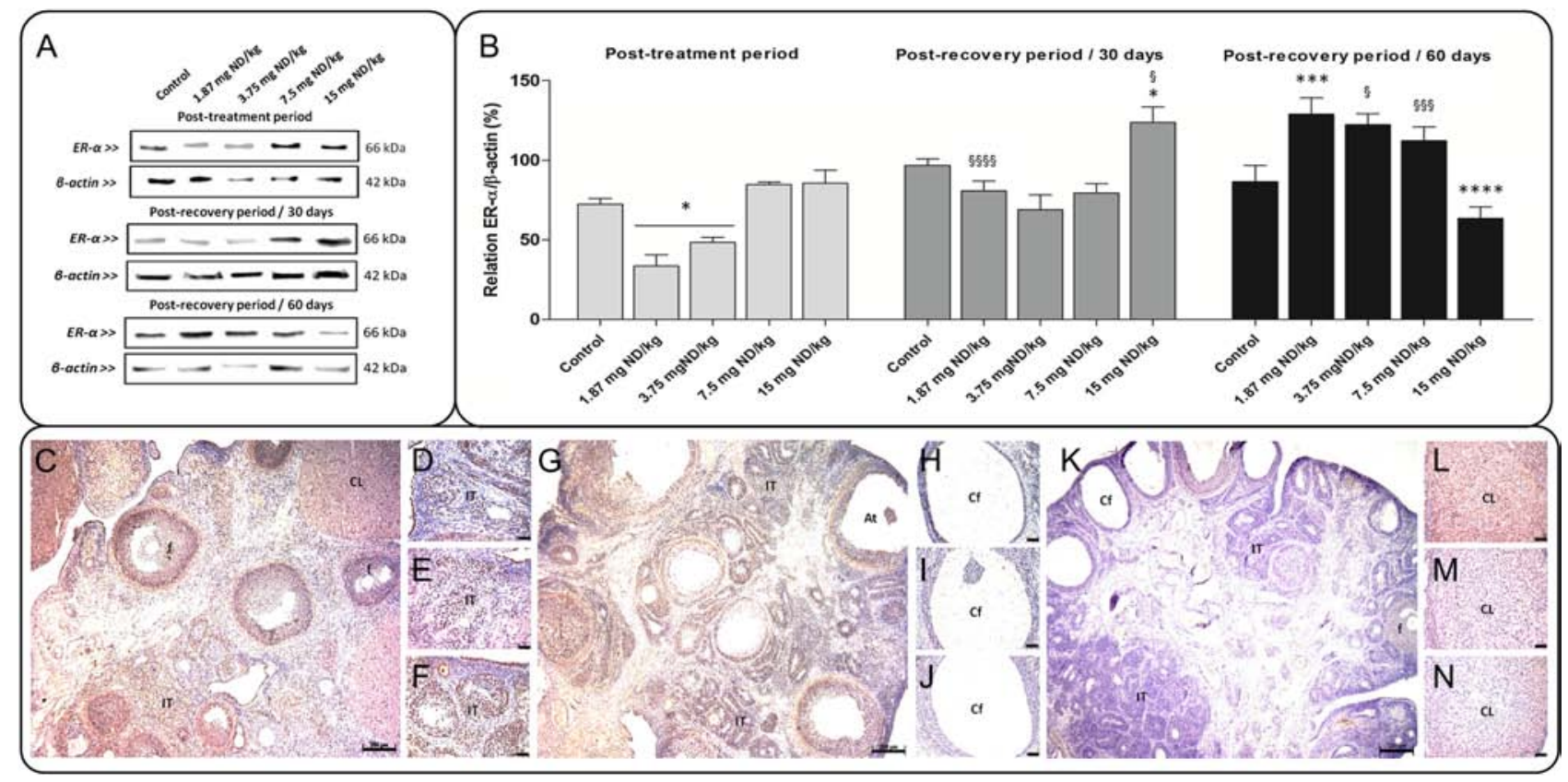

Figure 4 Western blot analysis and immunohistochemical localization of ER- $\alpha$ in the experimental groups after the ND treatment and 30- and 60 -day recovery. (A) Representation of the protein expression profiles $(70 \mu \mathrm{g})$ in pooled extracts of six samples/group. (B) The extracts obtained from the individual rats were used for densitometric analysis of ER- $\alpha$ levels followed by normalization of $\beta$-actin. ${ }^{*} P<0.05$ vs other groups; ${ }^{* * *} P<0.05$ vs control group; ${ }^{* * * *} P<0.05$ vs groups of $1.87,3.75$ and $7.5 \mathrm{mg} \mathrm{ND} / \mathrm{kg}$. ${ }^{\S} P<0.05$ vs respective group in other experimental periods; ${ } \$ P<0.05$ vs respective group in the 30 -day recovery period; $\$ \$ \$ \$ P<0.05$ vs the same experimental group among all the periods. Immunoreactivity for ER- $\alpha$ in the control group (D, G and L), and ND-treated groups at the doses of $1.87 \mathrm{mg} \mathrm{ND/kg}(\mathrm{C}, \mathrm{H}$ and M); $3.75 \mathrm{mg} \mathrm{ND} / \mathrm{kg}(\mathrm{E}, \mathrm{I}$ and $\mathrm{N}) ; 7.5 \mathrm{mg} \mathrm{ND} / \mathrm{kg}(\mathrm{J})$ and $15 \mathrm{mg} \mathrm{ND} / \mathrm{kg}(\mathrm{F}$ and $\mathrm{K})$ in the different periods of the study. $\mathrm{f}$ (healthy follicle); At (atretic follicle); Cf (cystic follicle); CL (corpora lutea); IT (interstitial tissue). Bar $=200 \mu \mathrm{m}$ (C, G and K) and $50 \mu \mathrm{m}(\mathrm{D}-\mathrm{F}, \mathrm{H}-\mathrm{J}$ and L-N). Negative control was used. Values expressed as the mean \pm S.E.M. ANOVA complemented by Tukey test. 
Staufen, Germany). Aliquots containing 1:10 (v/v) dilutions in Triton X-100 were added to the homogenate and samples were placed on dry ice for $2 \mathrm{~h}$ to improve the extraction. These suspensions were centrifuged at 21,912 $\mathbf{g}$ for $20 \mathrm{~min}$ at $4{ }^{\circ} \mathrm{C}$ and the pellet was discarded. Total protein was measured by colorimetric determination. All proteins were dissolved in $1.5 \times$ sample buffer and used for extraction and electrophoretic analysis in polyacrylamide gel (SDS-PAGE, Bio-Rad Laboratories). Equal amounts of protein $(70 \mu \mathrm{g})$ per well were placed into preformed gels of $4-12 \%$ acrylamide gradient (Amersham Biosciences) with an electrophoresis running buffer system Tris-glycine $(60 \mathrm{~mA}$ fixed for $2 \mathrm{~h}$ ). After electrophoresis, total proteins were electro-transferred ( $200 \mathrm{~mA}$ for $1.5 \mathrm{~h}$ fixed) to nitrocellulose membranes $0.2 \mu \mathrm{M}$ Tris-glycine-methanol buffer. The Kaleidoscope Prestained Standard (Bio-Rad) was used as a molecular weight marker. Then, the membranes were blocked with saline Tris buffer and Tween 20 (TBS-T) solution containing 3\% BSA at RT for $60 \mathrm{~min}$ and incubated at $4{ }^{\circ} \mathrm{C}$ overnight with primary antibody polyclonal anti-rabbit AR (NB300-551, Novus Biologicals); anti-rabbit monoclonal ER- $\alpha$ (NB110-56961, Novus Biologicals), anti-rabbit ER- $\beta$ (NB120-3577) and antirabbit polyclonal aromatase cytP450 (NBP1-19697, Novus Biologicals). All dilutions of $1: 500,1: 5000,1 \mu \mathrm{g} / \mathrm{mL}$ and $1: 1000$ were made in $1 \%$ BSA, respectively. This was followed by $3 \times 5 \mathrm{~min}$ washing in TBS-T, and then incubated for $2 \mathrm{~h}$ at RT with anti-rabbit secondary antibody conjugated to HRP (diluted 1:1000 in 1\% BSA; Sigma-Aldrich Chemicals). After sequential washings, the bands were detected using a Chemiluminescent Substrate Kit (GE Healthcare) according to the manufacturer's instructions. Band intensity was captured by the CCD camera (G:BOX Chemi, Syngen, Sacramento, CA, USA). The integrated optical density of the bands was measured using ImageJ software (National Institutes of Health, Bethesda, MD, USA) to compare protein levels. $\beta$-actin was used as an endogenous control, and positive results were expressed as the mean \pm standard error (s.E.M.). Immunoblots (\%) were represented as optical densitometry values (band intensity/ $\beta$-actin ratio).

\section{Hormonal assays}

Blood samples were collected (08:00-10:30h) into Falcon tubes from the trunk of decapitated females of each experimental group ( $n=18 /$ group). Serum samples were obtained by centrifugation at $1200 \mathrm{~g}$ for $15 \mathrm{~min}$ at $4^{\circ} \mathrm{C}$ and stored at $-20^{\circ} \mathrm{C}$ until assayed. Serum levels of FSH (KT15332, Kamiya Biomedical Company, Seattle, WA, USA), LH (026.576, Bioassay, Swampscott, MA, USA), $P_{4}$ (582.601), $\mathrm{E}_{2}$ (582.251), T (582.701) (Cayman Chemical Company) and DHT (KA1886, Abnova, Walnut, CA, USA) were measured by enzyme-linked immunosorbent assay, and the reading was performed in an Epoch Spectrophotometer (BioTek) according to the manufacturer's instructions. The sensitivity and intra- or inter-assay coefficients of variation for each hormone were $1.18 \mathrm{ng} / \mathrm{mL}, 10 \%$ and $12 \%$ for $\mathrm{FSH} ; 144.2 \mathrm{pg} / \mathrm{mL}, 10 \%$ and $12 \%$ for $\mathrm{LH} ; 10 \mathrm{pg} / \mathrm{mL}, 54.5 \%$ and $16.4 \%$ for $\mathrm{P}_{4} ; 19 \mathrm{pg} / \mathrm{mL}$, $31 \%$ and $35.1 \%$ for $\mathrm{E}_{2} ; 6 \mathrm{pg} / \mathrm{mL}, 19.1 \%$ and $14.2 \%$ for $\mathrm{T}$ and $6 \mathrm{pg} / \mathrm{mL}, 11.4 \%$ and $12.1 \%$ for DHT. Serum levels are reported as $\mathrm{ng} / \mathrm{mL}$.

Table 2 Immunolocalization and intensity of ER- $\alpha$ in the ovaries of different experimental groups, after treatment and recovery periods.

\begin{tabular}{|c|c|c|c|c|c|}
\hline \multirow[b]{2}{*}{ Parameters } & \multicolumn{5}{|c|}{ Experimental groups ( $n=6 /$ group) } \\
\hline & Control & $1.87 \mathrm{mg} \mathrm{ND} / \mathrm{kg}$ & $3.75 \mathrm{mg} \mathrm{ND} / \mathrm{kg}$ & $7.5 \mathrm{mg} \mathrm{ND} / \mathrm{kg}$ & $15 \mathrm{mg} \mathrm{ND} / \mathrm{kg}$ \\
\hline \multicolumn{6}{|l|}{ Post-treatment period } \\
\hline Primordial follicles & $++/+$ & $+/++$ & + & $+/++$ & $+/++$ \\
\hline Primary follicles & + & $++/+^{N}$ & $+/++$ & ++ & $+/++$ \\
\hline Growing follicles & $+++^{\mathrm{C}}+^{\mathrm{N}}$ & $+++^{\mathrm{C}}++^{\mathrm{N}}$ & $+++^{\mathrm{C}}++^{\mathrm{N}} /++^{\mathrm{N}}$ & $+++^{\mathrm{C}}++^{\mathrm{N}}$ & $+++^{\mathrm{C}}++^{\mathrm{N}}$ \\
\hline Antral follicles & $+++^{\mathrm{C}}++^{\mathrm{N}} /+^{\mathrm{N}}$ & $+++^{\mathrm{C}}++^{\mathrm{N}}$ & $+++^{\mathrm{C}}++^{\mathrm{N}} /+^{\mathrm{N}}$ & $+++^{\mathrm{C}}++^{\mathrm{N}}$ & $+++^{\mathrm{C}}++^{\mathrm{N}}$ \\
\hline Atretic follicles & $++/+$ & $+++^{\mathrm{C}}++^{\mathrm{N}}$ & $+++^{\mathrm{C}}++^{\mathrm{N}}$ & $+++^{\mathrm{C}}++^{\mathrm{N}}$ & $+++^{\mathrm{C}}++^{\mathrm{N}} /+++^{\mathrm{N}}$ \\
\hline Cystic follicles & $*$ & ++ & $++^{\mathrm{C}}+++^{\mathrm{N}}$ & $+++^{\mathrm{C}}++^{\mathrm{N}}$ & +++ \\
\hline Corpora lutea & $++^{\mathrm{C}}$ & $+^{\mathrm{C}}$ & $+^{\mathrm{C}}$ & $++/+^{C}$ & $++^{\mathrm{C}}$ \\
\hline Interstitial tissue & ++ & ++ & ++ & ++ & +++ \\
\hline \multicolumn{6}{|c|}{ Post-recovery period/30 days } \\
\hline Primordial follicles & $++/+$ & $+/-$ & - & $+/-$ & $++/+++$ \\
\hline Primary follicles & $++^{\mathrm{C}}++^{\mathrm{N}} /+++^{\mathrm{C}}$ & ++ & + & $+/++$ & $++/+++$ \\
\hline Growing follicles & $+++^{\mathrm{C}}++^{\mathrm{N}}$ & $+++^{\mathrm{C}}++^{\mathrm{N}}$ & $++^{\mathrm{C}}+{ }^{\mathrm{N}}$ & $++/+$ & $+++^{\mathrm{C}}++^{\mathrm{N}}$ \\
\hline Antral follicles & $+++^{\mathrm{C}}++^{\mathrm{N}} /+^{\mathrm{N}}$ & $+++^{\mathrm{C}}++^{\mathrm{N}}$ & $+++^{\mathrm{C}}++^{\mathrm{N}}$ & $+++^{\mathrm{C}}++^{\mathrm{N}}$ & $+++^{\mathrm{C}}++^{\mathrm{N}}$ \\
\hline Atretic follicles & $++^{\mathrm{C}}+{ }^{\mathrm{N}}$ & + & $+++^{\mathrm{C}}+{ }^{\mathrm{N}}$ & $+++^{\mathrm{C}}++^{\mathrm{N}}$ & $+++^{\mathrm{C}}++^{\mathrm{N}}$ \\
\hline Cystic follicles & * & $++^{\mathrm{C}}+{ }^{\mathrm{N}}$ & + & $+/++^{C}$ & $+++^{\mathrm{C}}++^{\mathrm{N}}$ \\
\hline Corpora lutea & ++ & $*$ & + & + & ++ \\
\hline Interstitial tissue & ++ & $+\mathrm{N} /++^{\mathrm{N}}$ & $++^{N}$ & $-1+$ & $++\mathrm{N} /+++^{\mathrm{N}}$ \\
\hline \multicolumn{6}{|c|}{ Post-recovery period/60 days } \\
\hline Primordial follicles & + & + & + & + & + \\
\hline Primary follicles & $++^{\mathrm{C}}+{ }^{\mathrm{N}}$ & $++^{\mathrm{C}}+\mathrm{N} /+^{\mathrm{C}}$ & $++^{\mathrm{C}}+{ }^{\mathrm{N}}$ & + & $+/++$ \\
\hline Growing follicles & $+++^{\mathrm{C}}++^{\mathrm{N}}$ & $++^{\mathrm{C}}+{ }^{\mathrm{N}}$ & $++^{\mathrm{C}}+\mathrm{N} /+^{\mathrm{C}}$ & + & $++^{\mathrm{C}}+{ }^{\mathrm{N}}$ \\
\hline Antral follicles & $+++^{\mathrm{C}}++^{\mathrm{N}} /+++^{\mathrm{N}}$ & $++^{\mathrm{C}}+\mathrm{N} /+^{\mathrm{C}}$ & $++^{\mathrm{C}}+{ }^{\mathrm{N}}$ & $++^{\mathrm{C}}+{ }^{\mathrm{N}}$ & $++^{\mathrm{C}}+{ }^{\mathrm{N}}$ \\
\hline Atretic follicles & $++^{\mathrm{C}}++^{\mathrm{N}} /++^{\mathrm{N}}$ & $++^{\mathrm{C}}+\mathrm{N} /+^{\mathrm{C}}$ & $++^{\mathrm{C}}+{ }^{\mathrm{N}}$ & $++^{\mathrm{C}}+{ }^{\mathrm{N}}$ & $++^{\mathrm{C}}+{ }^{\mathrm{N}}$ \\
\hline Cystic follicles & $*$ & $++^{\mathrm{C}}+{ }^{\mathrm{N}}$ & $++^{\mathrm{C}}+{ }^{\mathrm{N}}$ & $++^{\mathrm{C}}+{ }^{\mathrm{N}}$ & $++^{\mathrm{C}}+{ }^{\mathrm{N}}$ \\
\hline Corpora lutea & $+++{ }^{C}$ & $++^{\mathrm{C}}+{ }^{\mathrm{N}}$ & $++^{\mathrm{C}}+{ }^{\mathrm{N}}$ & * & * \\
\hline Interstitial tissue & ++ & $++^{\mathrm{C}}+{ }^{\mathrm{N}}$ & $++/+^{N}$ & + & + \\
\hline
\end{tabular}

Reactions were classified as strong $(+++)$, moderate $(++)$, low $(+)$ and absent $(-)$.

*Structure absent in the ovaries. ${ }^{\mathrm{C}, \mathrm{N}}$ Different staining intensities in the cytoplasm $(\mathrm{C})$ and nucleus $(\mathrm{N})$. 


\section{Statistical analysis}

Data were analyzed by analysis of variance (ANOVA) followed by Tukey's test. All experimental groups were compared into each study period (post-treatment, post-recovery for 30 days and post-recovery for 60 days). For Western blot analysis, the comparison of each ovarian receptor in different periods and for each ND dose level was considered. The results were expressed as the mean \pm standard error (S.E.M.). Statistical significance was set at $P<0.05$. Statistical analysis was performed using GraphPad Prism software, version 5.00 (GraphPad Software).

\section{Results}

\section{Androgen treatment alters estrous cycle in a dose- and time-dependent manner}

Considering all the ND doses, the rats showed a significant increase in the number of days in diestrus (Fig. 2A), which persisted until the 30-day recovery period (Fig. 2B). At 60 days of recovery, the animals treated with the lower doses (1.87 and $3.75 \mathrm{mg} \mathrm{ND} /$ $\mathrm{kg}$ ) restored the cycle in the 48th and 55th days respectively, and the total number of days in diestrus was 51 and 57 respectively (Fig. 2C). Conversely, animals treated with $7.5 \mathrm{mgND} / \mathrm{kg}$ exhibited diestrus until the 59th day, and after treatment with $15 \mathrm{mg} \mathrm{ND} / \mathrm{kg}$, the animals arrested at diestrus until 60-day recovery (Fig. 2C).

\section{$A R, E R-\alpha, E R-\beta$ and aromatase CYP450 expressions are influenced by different doses of ND in ovarian tissue}

$A R$

After ND treatment period, animals receiving the dose of $15 \mathrm{mgND} / \mathrm{kg}$ presented the highest AR expression, compared with all other experimental groups (Fig. 3B). The doses of 3.75 and $7.5 \mathrm{mgND} / \mathrm{kg}$ had similar effects and showed an increase in the AR expression compared with control and $1.87 \mathrm{mgND} / \mathrm{kg}$ groups. Furthermore, AR showed moderate-to-strong immunoreactions in the granulosa cells of atretic and cystic follicles of ND-treated animals (Fig. 3C, E, F and Table 1). In control animals, the immunostaining intensity was moderate in the atretic follicles, and follicular cysts were not present (Fig. 3D and Table 1).

After 30 days of recovery, the AR expression increased significantly in all ND-treated groups (Fig. 3B). The strong AR immunostaining in the granulosa cells of atretic follicles was maintained and showed variations of moderate intensity in the cell cytoplasm or nucleus depending on specific dose (Fig. 3G, $\mathrm{H}$ and Table 1). Although the moderate intensity of AR was observed in cystic follicles (Fig. 3I,

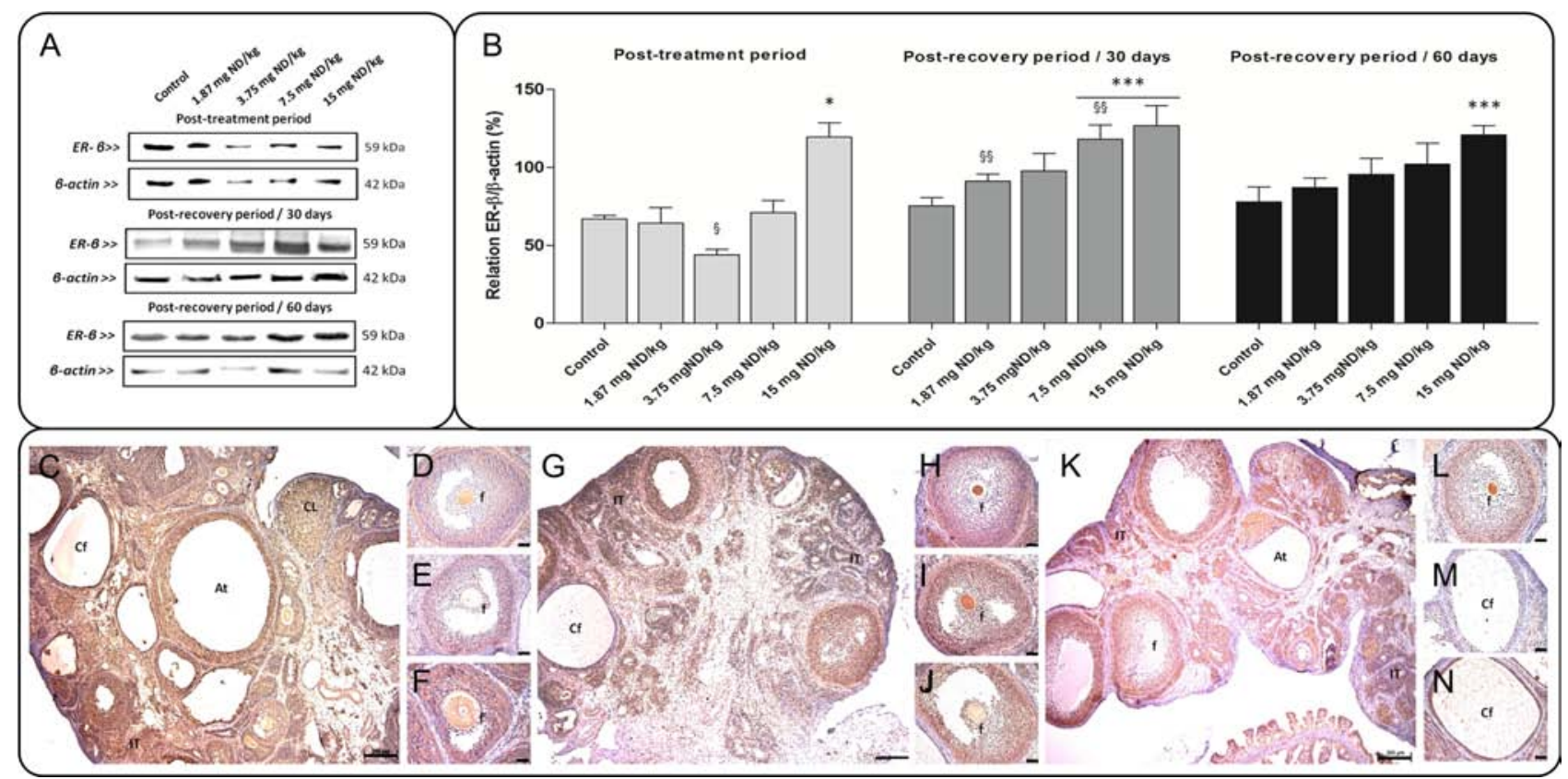

Figure 5 Western blot analysis and immunohistochemical localization of ER- $\beta$ in the experimental groups after the ND treatment and 30- and 60 -day recovery. (A) Representation of the protein expression profiles $(70 \mu \mathrm{g})$ in pooled extracts of six samples/group. (B) The extracts obtained from the individual rats were used for densitometric analysis of ER- $\beta$ levels followed by normalization of $\beta$-actin. ${ }^{*} P<0.05$ vs other groups; ${ }^{* * *} P<0.05$ vs control group. ${ }^{\circledR} P<0.05$ vs respective group in other experimental periods; ${ }^{\circledR}{ }^{\$} P<0.05$ vs respective group in the treatment period. Immunoreactivity for ER- $\beta$ in the control group (D, H and L), and ND-treated groups at the doses of $1.87 \mathrm{mg} \mathrm{ND/kg} \mathrm{(I} \mathrm{and} \mathrm{M);} 3.75 \mathrm{mg} \mathrm{ND} / \mathrm{kg}$ ( $\mathrm{E}$ and $\mathrm{J}) ; 7.5 \mathrm{mg} \mathrm{ND} / \mathrm{kg}(\mathrm{F}, \mathrm{G}$ and $\mathrm{K})$ and $15 \mathrm{mg} \mathrm{ND} / \mathrm{kg}(\mathrm{C}$ and $\mathrm{N})$ in the different periods of the study. $\mathrm{f}$ (healthy follicle); At (atretic follicle); Cf (cystic follicle); CL (corpora lutea); IT (interstitial tissue). Bar $=200 \mu \mathrm{m}(\mathrm{C}, \mathrm{G}$ and $\mathrm{K})$ and $50 \mu \mathrm{m}(\mathrm{D}-\mathrm{F}, \mathrm{H}-\mathrm{J}$ and L-N). Negative control was used. Values expressed as the mean \pm S.E.M. ANOVA complemented by Tukey test. 
J and Table 1), the granulosa layer of antral and growing follicles maintained moderate-to-high AR immunostaining (Fig. 3G and Table 1).

After 60 days of recovery, the AR expression was high in the androgenized ovaries, except to animals treated with $7.5 \mathrm{mg} \mathrm{ND/kg}$ (Fig. 3B). We observed high AR immunostaining in oocytes and in the cytoplasm of luteal cells in the groups of 1.87 and $3.75 \mathrm{mg} \mathrm{ND/}$ $\mathrm{kg}$ (Fig. $3 \mathrm{~K}$ and $\mathrm{M}$ ), compared with moderate intensity in the control group (Fig. $3 \mathrm{~L}$ ). There was a moderate staining intensity in the interstitial tissue and in primary, growing and antral follicles of ND-treated animals (Fig. $3 \mathrm{~N}$ and Table 1), having variations between cell nucleus and cytoplasm. There was a low AR immunostaining in the nucleus of granulosa cells of atretic and cystic follicles in ND-treated groups, and these reactions were reduced compared with the previous periods (Table 1 ).

AR expression was higher in animals treated with $3.75 \mathrm{mg} \mathrm{ND} / \mathrm{kg}$ after 30-day recovery than that with ND treatment and was lower in animals treated with $1.87 \mathrm{mg} \mathrm{ND} / \mathrm{kg}$, compared with both recovery periods (Fig. 3B).

\section{$E R-\alpha$}

After ND treatment, the animals treated with 1.87 and $3.75 \mathrm{mg} \mathrm{ND} / \mathrm{kg}$ had the lowest ER- $\alpha$ expression compared with that in the other groups (Fig. 4B).
ER- $\alpha$ immunostaining was moderate in the interstitial tissue of animals that received $1.87,3.75$ and $7.5 \mathrm{mg}$ $\mathrm{ND} / \mathrm{kg}$ (Fig. $4 \mathrm{C}$ and E) similar to control group (Fig. 4D). Only the dose of $15 \mathrm{mg} \mathrm{ND/kg}$ promoted a strong ER- $\alpha$ immunostaining (Fig. 4F and Table 2). $E R-\alpha$ also showed moderate staining in the nucleus and strong reaction in the cytoplasm of granulosa cells of growing, antral and atretic follicles (Fig. 4C and Table 2). In cystic follicles the immunostaining varied from moderate to strong according to the dosage (Table 2).

After 30 days of recovery, the ER- $\alpha$ expression was increased in the group of $15 \mathrm{mg} \mathrm{ND} / \mathrm{kg}$ (Fig. 4B). The granulosa layer of cystic follicles and the interstitial tissue had a reduced ER- $\alpha$ immunostaining in the groups treated with $1.87,3.75$ and $7.5 \mathrm{mg} \mathrm{ND} / \mathrm{kg}$ (Fig. $4 \mathrm{H}-\mathrm{J}$ and Table 2). Interestingly, a moderate-to-strong ER- $\alpha$ staining was common in animals treated with $15 \mathrm{mg}$ ND/kg (Fig. 4G and Table 2).

After 60-day recovery, a severe decrease in the ER- $\alpha$ expression and immunostaining was observed in the animals receiving $15 \mathrm{mg} \mathrm{ND} / \mathrm{kg}$ (Fig. 4B, K and Table 2). Otherwise, higher ER- $\alpha$ expression occurred at the lowest dose of steroid. After 60-day recovery, the ER- $\alpha$ immunoreaction was increased in animals that received 1.87 and $3.75 \mathrm{mg} \mathrm{ND} / \mathrm{kg}$, especially in the cytoplasm of luteal and interstitial cells, similar to the control group (Fig. $4 \mathrm{~L}-\mathrm{N}$ and Table 2).

In the comparison between the periods, ER- $\alpha$ expression was altered in a time-dependent manner

Table 3 Immunolocalization and intensity of ER- $\beta$ in the ovaries of different experimental groups, after treatment and recovery periods.

\begin{tabular}{|c|c|c|c|c|c|}
\hline \multirow[b]{2}{*}{ Parameters } & \multicolumn{5}{|c|}{ Experimental groups ( $n=6$ /group) } \\
\hline & Control & $1.87 \mathrm{mg} \mathrm{ND} / \mathrm{kg}$ & $3.75 \mathrm{mg} \mathrm{ND} / \mathrm{kg}$ & $7.5 \mathrm{mg} \mathrm{ND} / \mathrm{kg}$ & $15 \mathrm{mg} \mathrm{ND} / \mathrm{kg}$ \\
\hline \multicolumn{6}{|c|}{ Post-treatment period } \\
\hline Primordial follicles & +++ & +++ & $++/+++$ & +++ & +++ \\
\hline Primary follicles & $+++^{\mathrm{C}}++^{\mathrm{N}}$ & $+++^{\mathrm{C}}++^{\mathrm{N}}$ & $++/+++$ & $++/+++{ }^{C}$ & $+++^{\mathrm{C}}++^{\mathrm{N}}$ \\
\hline Growing follicles & $+++^{\mathrm{C}}++^{\mathrm{N}}$ & ++ & ++ & $++^{\mathrm{C}}+\mathrm{N} /+++^{\mathrm{C}}$ & $+++^{\mathrm{C}}++^{\mathrm{N}}$ \\
\hline Antral follicles & $+/++$ & $+++^{\mathrm{C}}++^{\mathrm{N}} /+^{\mathrm{N}}$ & $+++^{\mathrm{C}}++^{\mathrm{N}} /+^{\mathrm{N}}$ & $++/+++{ }^{\mathrm{C}}$ & $+++^{\mathrm{C}}++^{\mathrm{N}}$ \\
\hline Atretic follicles & + & $+++^{\mathrm{C}}+{ }^{\mathrm{N}} /++^{\mathrm{N}}$ & $+++{ }^{\mathrm{C}}++^{\mathrm{N}} /++^{\mathrm{C}}$ & $+++{ }^{\mathrm{C}}+{ }^{\mathrm{N}}$ & $+++^{\mathrm{C}}+{ }^{\mathrm{N}}$ \\
\hline Cystic follicles & $*$ & $+++^{\mathrm{C}}++^{\mathrm{N}} /+++^{\mathrm{N}}$ & $++^{\mathrm{C}}+++^{\mathrm{N}} /+++^{\mathrm{C}}$ & $+++^{\mathrm{C}}++^{\mathrm{N}} /++^{\mathrm{N}}$ & $+++^{\mathrm{C}}++^{\mathrm{N}} /+++^{\mathrm{N}}$ \\
\hline Corpora lutea & $+++^{\mathrm{C}}$ & $+++^{\mathrm{C}}$ & $++^{\mathrm{C}}$ & $+++^{\mathrm{C}}$ & $+++^{\mathrm{C}}$ \\
\hline Interstitial tissue & $+++^{\mathrm{C}}++^{\mathrm{N}}$ & $+++^{\mathrm{C}}++^{\mathrm{N}}$ & ++ & ++ & ++ \\
\hline \multicolumn{6}{|c|}{ Post-recovery period/30 days } \\
\hline Primordial follicles & +++ & ++ & ++ & ++ & +++ \\
\hline Primary follicles & $+++^{\mathrm{C}}++^{\mathrm{N}}$ & $++/+$ & $+/++$ & ++ & +++ \\
\hline Growing follicles & $++/+++C$ & $++/+++$ & $++/+++{ }^{C}$ & $+++{ }^{C}$ & $+++{ }^{C}$ \\
\hline Antral follicles & $++{ }^{\mathrm{C}}$ & +++ & +++ & +++ & +++ \\
\hline Atretic follicles & $++^{\mathrm{C}}$ & $+++/++C$ & +++ & +++ & $+++^{\mathrm{C}}++^{\mathrm{N}}$ \\
\hline Cystic follicles & $*$ & +++ & +++ & +++ & $+++^{\mathrm{C}}++^{\mathrm{N}}$ \\
\hline Corpora lutea & $+++{ }^{C}$ & $*$ & $+++{ }^{\mathrm{C}}$ & $+++{ }^{\mathrm{C}}$ & $+++{ }^{\mathrm{C}}$ \\
\hline Interstitial tissue & +++ & +++ & +++ & $+++/++$ & $+/++$ \\
\hline \multicolumn{6}{|c|}{ Post-recovery period/60 days } \\
\hline Primordial follicles & +++ & + & $+/++$ & $++/+$ & $+++/++$ \\
\hline Primary follicles & + & + & $++^{\mathrm{C}}+\mathrm{N} /++^{\mathrm{N}}$ & ++ & +++ \\
\hline Growing follicles & $+/++$ & $+{ }^{\mathrm{C}}$ & $++/+^{\mathrm{N}}$ & $++^{\mathrm{C}}+{ }^{\mathrm{N}}$ & $+++^{\mathrm{C}}++^{\mathrm{N}}$ \\
\hline Antral follicles & +++ & $+{ }^{\mathrm{C}}$ & ++ & ++ & $+++^{\mathrm{C}}++^{\mathrm{N}}$ \\
\hline Atretic follicles & + & + & $++^{\mathrm{C}}+\mathrm{N} /++^{\mathrm{N}}$ & + & $+++^{\mathrm{C}}++^{\mathrm{N}}$ \\
\hline Cystic follicles & $*$ & + & $++^{\mathrm{C}}++^{\mathrm{N}}$ & ++ & $+++^{\mathrm{C}}++^{\mathrm{N}}$ \\
\hline Corpora lutea & $+++{ }^{C}$ & $++^{\mathrm{C}}++^{\mathrm{N}} /+++^{\mathrm{C}}$ & $+++{ }^{\mathrm{C}}$ & $*$ & $*$ \\
\hline Interstitial tissue & $++/+++$ & $+++\mathrm{C} /+^{\mathrm{N}}$ & $+++^{\mathrm{C}}+{ }^{\mathrm{N}} /++^{\mathrm{N}}$ & $+++^{\mathrm{C}}++^{\mathrm{N}}$ & $++^{\mathrm{C}}++^{\mathrm{N}} /+++^{\mathrm{C}}$ \\
\hline
\end{tabular}

Reactions were classified as strong $(+++)$, moderate $(++)$, low $(+)$ and absent $(-)$.

*Structure absent in the ovaries. ${ }^{\mathrm{C}, \mathrm{N}}$ Different staining intensities in the cytoplasm $(\mathrm{C})$ and nucleus $(\mathrm{N})$. 
for all dosing levels (Fig. 4B). ER- $\alpha$ expression was higher in animals treated with $3.75 \mathrm{mgND} / \mathrm{kg}$ after 60 -day recovery. Likewise, ER- $\alpha$ expression was higher in animals treated with $7.5 \mathrm{mg} \mathrm{ND} / \mathrm{kg}$ after 60-day recovery, compared with that in 30-day recovery. The $E R-\alpha$ was differentially expressed in animals treated with $15 \mathrm{mg} \mathrm{ND} / \mathrm{kg}$ regarding to each period.

\section{$E R-\beta$}

After ND treatment, the levels of ER- $\beta$ were increased in the ovaries of animals treated with $15 \mathrm{mgND} / \mathrm{kg}$ (Fig. 5B). Moreover, the androgenized animals showed stronger ER- $\beta$ immunostaining in the cytoplasm and moderate-to-low staining in the nucleus of theca and granulosa cells of antral (Fig. 5E, F and Table 3) and atretic follicles (Fig. 5C and Table 3). Conversely, ER- $\beta$ immunostaining varied from low-to-moderate intensity in the control animals (Fig. 5D and Table 3).

After 30 days of recovery, the highest levels of ER- $\beta$ were observed in animals that received doses of 7.5 and $15 \mathrm{mg} \mathrm{ND} / \mathrm{kg}$ (Fig. 5B), compared with the control. In androgenized animals, a strong ER- $\beta$ immunostaining appeared in the oocyte, interstitial tissue and nucleus/cytoplasm of granulosa cells from antral (Fig. 5I and J), atretic and cystic follicles (Fig. 5G). In contrast, low or absent nuclear ER- $\beta$ immunostaining was observed in the granulosa cells of animals treated with $15 \mathrm{mg} \mathrm{ND/kg}$ similar to control animals (Fig. $5 \mathrm{H}$ and Table 3 ).

After 60 days of recovery, only animals treated with $15 \mathrm{mg} N D / k g$ presented higher ER- $\beta$ expression, compared with the control group (Fig. 5B). The increase in the intensity of ER- $\beta$ immunostaining in antral and cystic follicles was dose dependent (Table 3); for example, low intensity in the $1.87 \mathrm{mgND} / \mathrm{kg}$ group (Fig. 5M), moderate intensity in the 3.75 and $7.5 \mathrm{mgND} / \mathrm{kg}$ groups (Fig. 5K), and strong intensity in the cytoplasm of granulosa cells of $15 \mathrm{mgND} / \mathrm{kg}$ group (Fig. $5 \mathrm{~N}$ ). In addition, control ovaries showed variations in the ER- $\beta$ immunostaining according to the structure, such as a strong reaction in the cells of antral follicles (Fig. 5L and Table 3).

In the comparison between the periods, a significant increase of ovarian ER- $\beta$ appeared in animals treated with $3.75 \mathrm{mg} \mathrm{ND} / \mathrm{kg}$ with regard to 30- and 60-day recovery (Fig. 5B). The groups treated with 1.87 and $7.5 \mathrm{mg} \mathrm{ND/kg}$ showed higher ER- $\beta$ expression only after 30 days of recovery.

\section{Aromatase CYP450}

The expression of aromatase CYP450 increased significantly in the ND-treated groups after the treatment

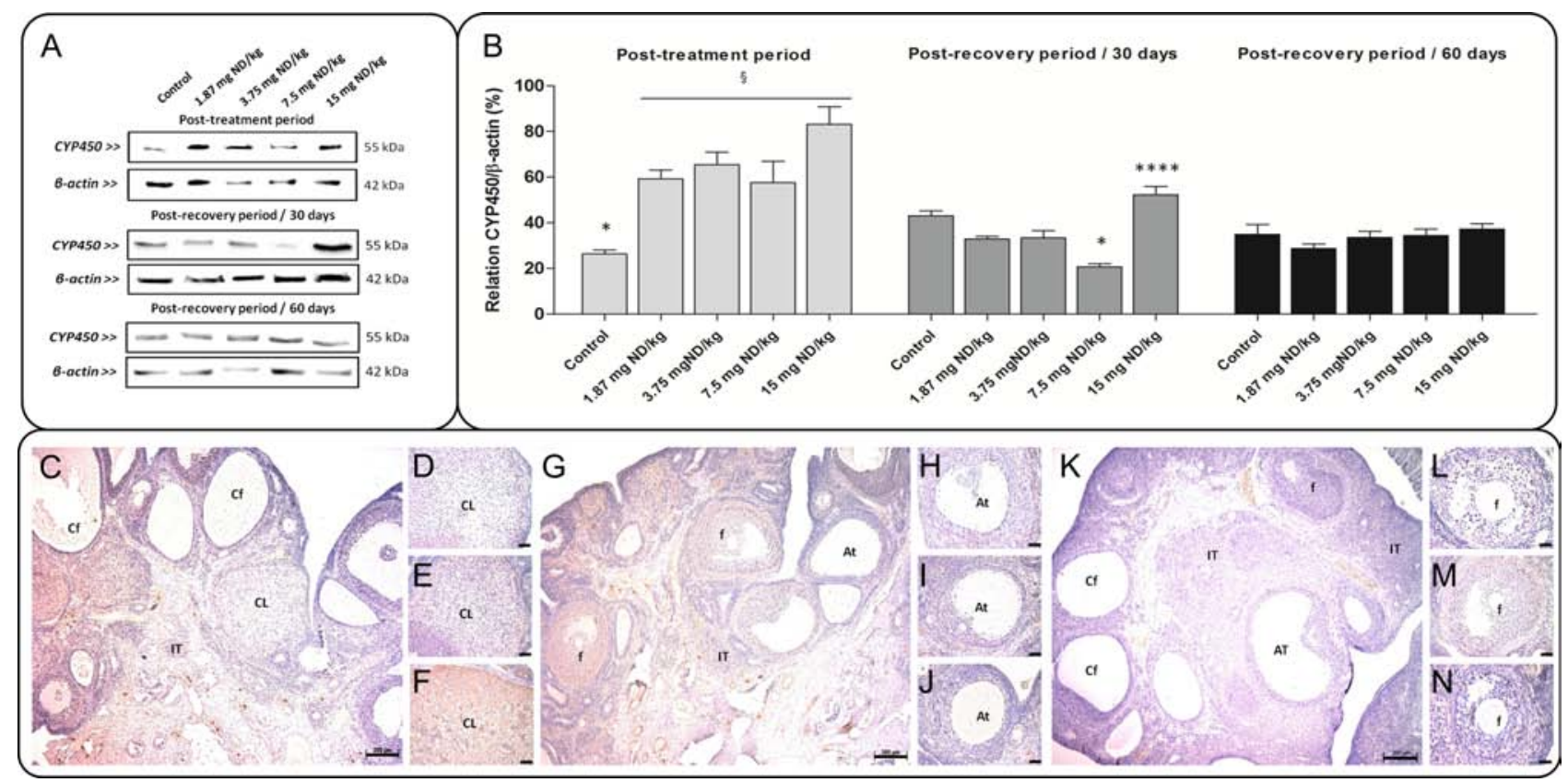

Figure 6 Western blot analysis and immunohistochemical localization of CYP450 in the experimental groups after the ND treatment and 30- and 60-day recovery. (A) Representation of the protein expression profiles $(70 \mu \mathrm{g})$ in pooled extracts of six samples/group. (B) The extracts obtained from the individual rats were used for densitometric analysis of CYP450 levels followed by normalization of $\beta$-actin. ${ }^{*} P<0.05$ vs other groups; ${ }^{* * * *} P<0.05$ vs groups of $1.87,3.75$ and $7.5 \mathrm{mg} \mathrm{ND} / \mathrm{kg}$. ${ }^{\circledR} P<0.05$ vs respective group in other experimental periods. Immunoreactivity for CYP450 in the control group (D, H and L), and ND-treated groups at the doses of $1.87 \mathrm{mg} \mathrm{ND} / \mathrm{kg}(\mathrm{E}$ and I); $3.75 \mathrm{mg} \mathrm{ND} / \mathrm{kg}(\mathrm{K}) ; 7.5 \mathrm{mg} \mathrm{ND} / \mathrm{kg}$ $(\mathrm{C}, \mathrm{J}$ and $\mathrm{M})$ and $15 \mathrm{mg} \mathrm{ND} / \mathrm{kg}(\mathrm{F}, \mathrm{G}$ and $\mathrm{N}$ ) in the different periods of the study. $\mathrm{f}$ (healthy follicle); At (atretic follicle); $\mathrm{Cf}$ (cystic follicle); $\mathrm{CL}$ (corpora lutea); IT (interstitial tissue). Bar $=200 \mu \mathrm{m}(\mathrm{C}, \mathrm{G}$ and $\mathrm{K})$ and $50 \mu \mathrm{m}(\mathrm{D}-\mathrm{F}, \mathrm{H}-\mathrm{J}$ and L-N). Negative control was used. Values expressed as the mean \pm S.E.M. ANOVA complemented by Tukey test. 
period (Fig. 6B). However, no significant effect was observed while following different ND doses. Notably, aromatase immunostaining varied from low to moderate intensity in different ovarian structures (Fig. 6C and Table 4). There was also an increase of aromatase CYP450 levels in the luteal cells of animals treated with 1.87 and $15 \mathrm{mg} \mathrm{ND} / \mathrm{kg}$ (Fig. 6E and F), compared with control (Fig. 6D), and those treated with 3.75 and $7.5 \mathrm{mg} \mathrm{ND} / \mathrm{kg}$ (Fig. 6C and Table 4).

At 30-day recovery, the aromatase expression was reduced in animals treated with $7.5 \mathrm{mg} \mathrm{ND} / \mathrm{kg}$, compared with that in the other groups (Fig. 6A and B). Furthermore, the highest dose of $15 \mathrm{mg} \mathrm{ND} / \mathrm{kg}$ differed significantly from the other steroidal groups. In atretic follicles, aromatase immunostaining was moderate in the cytoplasm and low in the nucleus of granulosa cell with regard to ND-treated groups (Fig. 6G, I, J and Table 4). In control animals, the intensity of aromatase staining was low (Fig. $6 \mathrm{H}$ and Table 4).

After 60-day recovery, the expression of aromatase CYP450 was similar in all experimental groups (Fig. 6B). The immunohistochemical analysis showed low-to-absent staining intensity in the granulosa cells of antral and atretic follicles in the ND-treated (Fig. 6K and $M$ ) and control animals (Fig. 6L and Table 4), with the exception of the animals treated with $15 \mathrm{mg} \mathrm{ND} / \mathrm{kg}$, which showed moderate cytoplasmic staining in the granulosa cells of antral follicles (Fig. 6N).

In the comparison between the periods, a significant decrease in the ovarian aromatase was common for all dosing levels after interruption of ND treatment (Fig. 6B).

\section{Ovarian sex hormone levels varied in a dose- and period-dependent manner}

Serum levels of FSH were unchanged after ND treatment and 30 days of recovery. Only at 60-day recovery, animals treated with $7.5 \mathrm{mgND} / \mathrm{kg}$ presented a decrease in $\mathrm{FSH}$ levels (Fig. 7A). In contrast, LH levels varied in a dose- and period-dependent manner. ND-treated animals showed an increase in LH levels, especially in the doses of 3.75, 7.5 and $15 \mathrm{mg} \mathrm{ND} / \mathrm{kg}$. After 30-day recovery, a significant increase in LH levels was observed in animals treated with $7.5 \mathrm{mgND} / \mathrm{kg}$ compared with those in $1.87 \mathrm{mg} \mathrm{ND} /$ $\mathrm{kg}$. After 60-day recovery, animals receiving the dose of $15 \mathrm{mgND} / \mathrm{kg}$ had higher LH levels, in comparison with the control group (Fig. 7B). $\mathrm{P}_{4}$ levels were reduced after ND treatment and 30 days of recovery in all androgenized animals (Fig. 7C). In addition, animals treated with doses of 1.87 and $15 \mathrm{mgND} / \mathrm{kg}$ had lower $\mathrm{P}_{4}$ levels compared with the animals treated with the intermediate doses (3.75 and $7.5 \mathrm{mgND} / \mathrm{kg}$ ). After 60 days of recovery, the animals treated with the lowest two doses restored $\mathrm{P}_{4}$ to the levels of

Table 4 Immunolocalization and intensity of aromatase CYP450 enzyme in the ovaries of different experimental groups, after treatment and recovery periods.

\begin{tabular}{|c|c|c|c|c|c|}
\hline \multirow[b]{2}{*}{ Parameters } & \multicolumn{5}{|c|}{ Experimental groups ( $n=6 /$ group) } \\
\hline & Control & $1.87 \mathrm{mg} \mathrm{ND} / \mathrm{kg}$ & $3.75 \mathrm{mg} \mathrm{ND} / \mathrm{kg}$ & $7.5 \mathrm{mg} \mathrm{ND} / \mathrm{kg}$ & $15 \mathrm{mg} \mathrm{ND} / \mathrm{kg}$ \\
\hline \multicolumn{6}{|l|}{ Post-treatment period } \\
\hline Primordial follicles & $+/-$ & + & - & - & ++ \\
\hline Primary follicles & + & $++^{\mathrm{C}}+{ }^{\mathrm{N}}$ & $-1+$ & + & $++^{\mathrm{C}}+{ }^{\mathrm{N}}$ \\
\hline Growing follicles & + & ++ & + & $++^{\mathrm{C}}++^{\mathrm{N}} /+^{\mathrm{C}}$ & ++ \\
\hline Antral follicles & + & ++ & $++^{\mathrm{C}}+{ }^{\mathrm{N}}$ & $++^{\mathrm{C}}++^{\mathrm{N}} /+^{\mathrm{C}}$ & $+++{ }^{\mathrm{C}}+{ }^{\mathrm{N}} /++^{\mathrm{N}}$ \\
\hline Atretic follicles & + & $++^{\mathrm{C}}++^{\mathrm{N}} /+++^{\mathrm{C}}$ & $++^{\mathrm{C}}++^{\mathrm{N}}$ & $++^{\mathrm{C}}+{ }^{\mathrm{N}}$ & $+++^{\mathrm{C}}++^{\mathrm{N}} /++^{\mathrm{C}}$ \\
\hline Cystic follicles & $*$ & $++^{\mathrm{C}}++^{\mathrm{N}}$ & $++^{\mathrm{C}}+{ }^{\mathrm{N}} /+^{\mathrm{C}}$ & $++^{\mathrm{C}}+{ }^{\mathrm{N}} /+++^{\mathrm{C}}++^{\mathrm{N}}$ & $+++^{\mathrm{C}}++^{\mathrm{N}} /++^{\mathrm{N}}$ \\
\hline Corpora lutea & + & ++ & + & + & ++ \\
\hline Interstitial tissue & $++^{\mathrm{C}}+\mathrm{N} /+^{\mathrm{C}}$ & + & $+/-$ & + & $++^{\mathrm{C}}+{ }^{\mathrm{N}} /+^{\mathrm{C}}$ \\
\hline \multicolumn{6}{|c|}{ Post-recovery period/30 days } \\
\hline Primordial follicles & + & $-/+$ & - & - & $+/-$ \\
\hline Primary follicles & + & ++ & + & + & + \\
\hline Growing follicles & $++^{\mathrm{C}}+\mathrm{N} /+^{\mathrm{C}}$ & ++ & $++^{\mathrm{C}}+{ }^{\mathrm{N}}$ & + & + \\
\hline Antral follicles & $++^{\mathrm{C}}+\mathrm{N} /+^{\mathrm{C}}$ & ++ & ++ & ++ & + \\
\hline Atretic follicles & + & $++^{\mathrm{C}}++^{\mathrm{N}}$ & $++^{\mathrm{C}}++^{\mathrm{N}}$ & $++^{\mathrm{C}}++^{\mathrm{N}}$ & $++^{\mathrm{C}}++^{\mathrm{N}}$ \\
\hline Cystic follicles & $*$ & $++^{\mathrm{C}}+{ }^{\mathrm{N}}$ & $++^{\mathrm{C}}+{ }^{\mathrm{N}}$ & $+/-^{N}$ & $++^{\mathrm{C}}+{ }^{\mathrm{N}}$ \\
\hline Corpora lutea & ++ & $*$ & + & + & + \\
\hline Interstitial tissue & $++^{\mathrm{C}}+{ }^{\mathrm{N}}$ & + & + & - & - \\
\hline \multicolumn{6}{|c|}{ Post-recovery period/60 days } \\
\hline Primordial follicles & $+/-$ & + & + & $-/+$ & - \\
\hline Primary follicles & $+{ }^{\mathrm{C}} /+^{\mathrm{N}}$ & + & + & + & $++^{C}$ \\
\hline Growing follicles & $++^{\mathrm{C}}+{ }^{\mathrm{N}} /+^{\mathrm{C}}$ & $+{ }^{\mathrm{C}}$ & $++^{\mathrm{C}}+{ }^{\mathrm{N}}$ & $++^{\mathrm{C}}$ & $++{ }^{\mathrm{C}}$ \\
\hline Antral follicles & + & $+^{\mathrm{C}}$ & + & $+{ }^{\mathrm{C}}$ & $++^{\mathrm{C}}++^{\mathrm{N}}$ \\
\hline Atretic follicles & $+/-^{N}$ & $+\mathrm{C} /{ }_{-} \mathrm{C}$ & $+/{ }^{N}$ & $+^{\mathrm{C}}$ & $+^{\mathrm{C}}$ \\
\hline Cystic follicles & $*$ & $++^{C}$ & $++^{\mathrm{C}}+\mathrm{N} /-^{\mathrm{N}}$ & $+{ }^{\mathrm{C}}$ & $+^{\mathrm{C}}$ \\
\hline Corpora lutea & + & + & $++^{\mathrm{C}}+{ }^{\mathrm{N}}$ & $*$ & $*$ \\
\hline Interstitial tissue & + & + & + & + & - \\
\hline
\end{tabular}

Reactions were classified as strong $(+++)$, moderate $(++)$, low $(+)$ and absent $(-)$.

*Structure absent in the ovaries. ${ }^{\mathrm{C}, \mathrm{N}}$ Different staining intensities in the cytoplasm $(\mathrm{C})$ and nucleus $(\mathrm{N})$. 

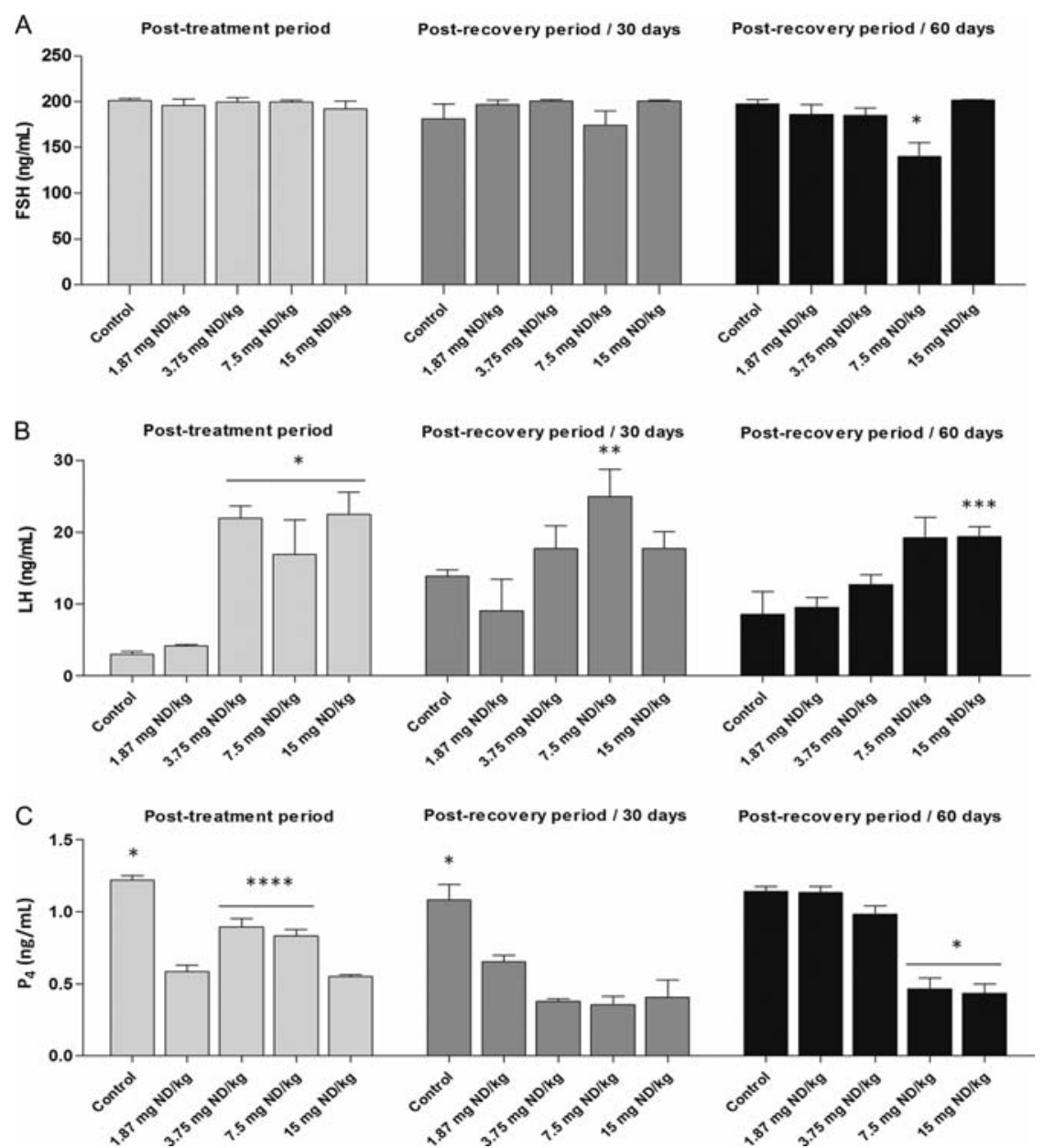

Figure 7 Hormonal profile of the experimental groups after the ND treatment and 30- and 60-day recovery. (A) FSH levels $(\mathrm{ng} / \mathrm{mL}$ ), (B) $\mathrm{LH}$ levels $(\mathrm{ng} / \mathrm{mL})$ and $(\mathrm{C}) \mathrm{P}_{4}$ levels $(\mathrm{ng} / \mathrm{mL})$. ${ }^{*} P<0.05$ vs other groups; ${ }^{* *} P<0.05$ vs group of $1.87 \mathrm{mg} \mathrm{ND} / \mathrm{kg} ;{ }^{* * *} P<0.05$ vs control group; ${ }^{* * * *} P<0.05$ vs groups of 1.87 and $15 \mathrm{mg} \mathrm{ND} / \mathrm{kg}$. Values expressed as the mean \pm S.E.M. ANOVA complemented by Tukey test. control group. Serum $\mathrm{P}_{4}$ remained at low levels in animals treated with 7.5 and $15 \mathrm{mg} \mathrm{ND} / \mathrm{kg}$. In ND-treated animals, $E_{2}$ levels were higher at doses of 7.5 and $15 \mathrm{mgND} / \mathrm{kg}$. After 30 and 60 days of recovery, a significant decline in $E_{2}$ levels was found in androgenized animals (Fig. 8A). ND-treated animals that received doses of 3.75, 7.5 and $15 \mathrm{mg} \mathrm{ND} / \mathrm{kg}$ presented higher levels of T (Fig. 8B). At 30 and 60 days of recovery, $\mathrm{T}$ levels were decreased in ND-treated animals compared with the post-treatment period. However, $\mathrm{T}$ levels remained higher in animals treated with the dose of $15 \mathrm{mgND} / \mathrm{kg}$. DHT levels were higher in ND-treated animals (Fig. 8C). After 30 days of recovery, DHT levels remained elevated in animals treated with doses of 7.5 and $15 \mathrm{mg} \mathrm{ND} / \mathrm{kg}$. In this period, there was difference in hormone levels between the $1.87 \mathrm{mg} \mathrm{ND} / \mathrm{kg}$ group and those who received the two highest ND doses. After 60 days of recovery, animals treated with $15 \mathrm{mg} \mathrm{ND/kg}$ had higher DHT levels compared with the control, $1.87 \mathrm{mgND} / \mathrm{kg}$, and $3.75 \mathrm{mg} \mathrm{ND} / \mathrm{kg}$ groups (Fig. 8C).

\section{Discussion}

This study evaluated the immunolocalization and quantification of AR, ER- $\alpha, E R-\beta$ and aromatase CYP450 in ovarian tissue as well as the hormonal levels of FSH, $\mathrm{LH}, \mathrm{E}_{2}, \mathrm{P}_{4}, \mathrm{~T}$ and $\mathrm{DHT}$ in rats treated with different doses of ND in the post-treatment and post-recovery periods.

The deleterious effects promoted by different doses of ND on ovarian folliculogenesis and luteogenesis were reported previously (Simão et al. 2015). Here, we observed that these effects negatively influenced the estrous cycle, indicating a condition of 'pseudo diestrous' (Mannerås et al. 2007) occurring during the ND treatment and 30-day recovery period. The impairment in the estrous cycle was maintained until 60 days of recovery in the higher dose of $15 \mathrm{mg} \mathrm{ND} / \mathrm{kg}$. These results indicated that the ND presented dose- and time-dependent effect on the estrous cycle.

It is well documented that anabolic steroids may dramatically affect the reproductive cycle of the females (Gerez et al. 2005, Mobini Far et al. 2007, Bento-Silva et al. 2010, Chuffa et al. 2011c, Camargo et al. 2011, 2014, Belardin et al. 2014). Most studies have attributed this effect to inhibition of the production and release of pituitary gonadotropins, due to an increase in the levels of circulating androgens (Bronson et al. 1996, Karbalay-Doust \& Noorafshan 2012). However, the reports are merely suggestive because the effects of AAS on the hypothalamic-pituitary-gonadal axis in females 


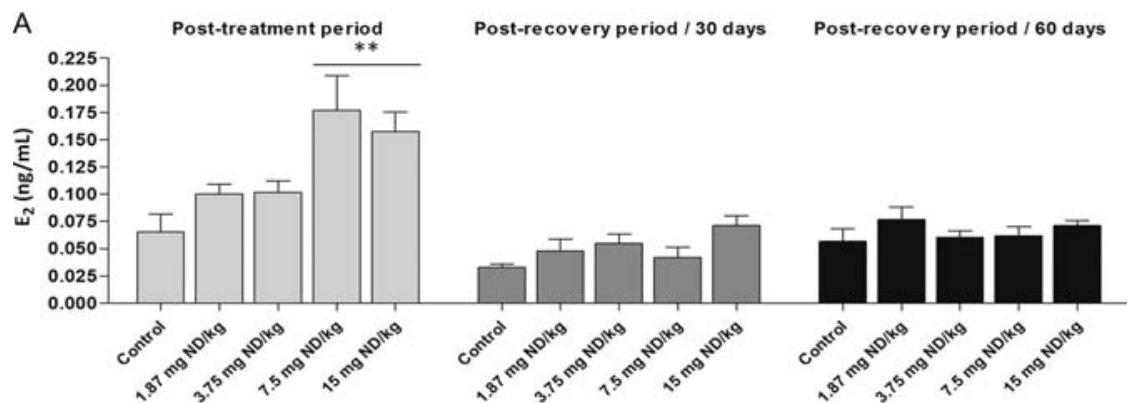

B

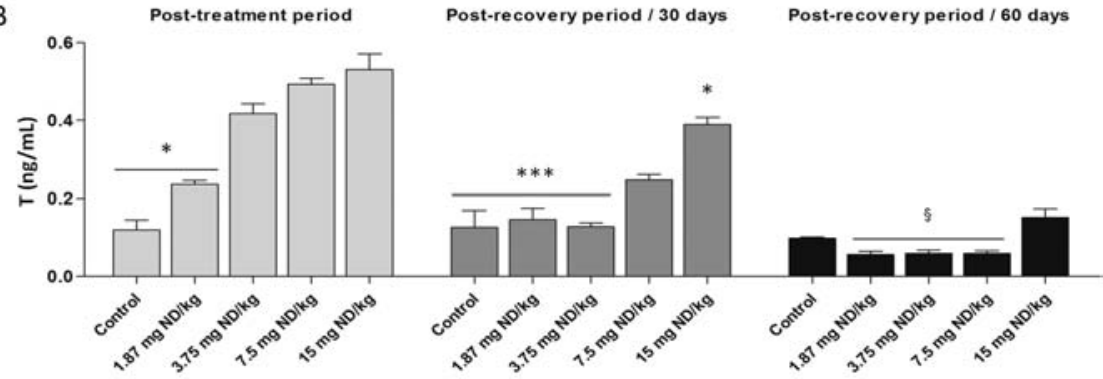

C

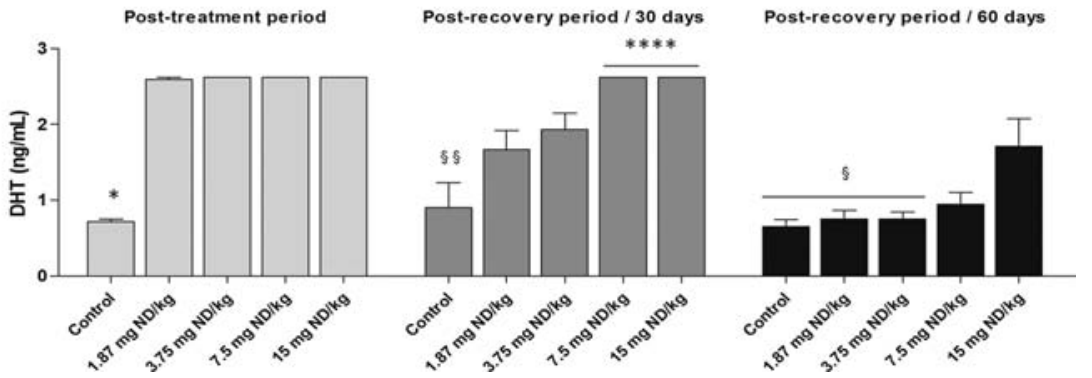

Figure 8 Hormonal profile of the experimental groups after ND treatment and 30- and 60-day recovery. (A) $E_{2}$ levels $(n g / m L),(B) T$ levels $(\mathrm{ng} / \mathrm{mL})$ and $(\mathrm{C})$ DHT levels $(\mathrm{ng} / \mathrm{mL}) .{ }^{*} P<0.05$ vs other groups; ${ }^{* *} P<0.05$ vs control group; *** $P<0.05$ vs groups of 7.5 and $15 \mathrm{mg} \mathrm{ND} / \mathrm{kg}$; $* * * * P<0.05$ vs group of $1.87 \mathrm{mg} \mathrm{ND} / \mathrm{kg}$; ${ }^{\S} P<0.05$ vs group of $15 \mathrm{mg} \mathrm{ND} / \mathrm{kg} ;{ }^{\circledR} P P<0.05$ vs group of $3.75,7.5$ and $15 \mathrm{mg} \mathrm{ND} / \mathrm{kg}$. Values expressed as the mean \pm S.E.M. ANOVA complemented by Tukey test. are poorly understood (Kuipers 1998). According to Gervásio and coworkers (2014), hypersecretion of LH in excessively androgenic ovaries may lead to chronic anovulation and infertility. In fact, we observed an increase in $\mathrm{LH}$ levels following doses higher than $3.75 \mathrm{mg} \mathrm{ND} / \mathrm{kg}$ after ND treatment, and also in the 7.5 and $15 \mathrm{mg} \mathrm{ND} / \mathrm{kg}$ doses after the recovery periods of 30 and 60 days, respectively. This hormonal change may be responsible for the suppression of the reproductive capacity of rats in post-treatment and post-recovery periods, as already confirmed in an earlier study by Belardin and coworkers (2014).

Ovarian sex steroid hormones, including androgens and estrogens, regulate the process of folliculogenesis after binding to their specific receptors. The increased incidence of atretic follicles and follicular cysts and the presence of occasional corpora lutea observed in androgenized groups have been described in other experimental studies (Gerez et al. 2005, Camargo et al. 2011, 2014), in transsexual patients treated with high doses of androgen over a long period (Chadha et al. 1994), and in animal models of 'PCOS' (Tehrani et al. 2014).

In PCOS rat model, the females are treated with synthetic androgens before puberty to activate ARs; in the adult age, the ovaries exhibit follicular cysts characterized by a thickened theca interna cell layer and scarce granulosa cells (Mannerås et al. 2007, Wu et al. 2014). In this study, the ovaries from the ND-treated groups showed cystic formations with some morphological characteristics similar to PCOS, such as a thin layer of granulosa cells and size greater than the preovulatory follicles. However, the cyst wall did not show a vascularized and luteinized granulosa layer as reported by Mannerås and coworkers (2007). It must be considered that the cystic phenotype in PCOS is the result of an arrest of antral follicle growth in the final stages of maturation (Honnma et al. 2010, Badawy \& Elnashar 2011). The follicular cysts observed in the ovaries of ND-treated groups probably resulted from the stimulation of follicular atresia induced by androgens.

According to Walters (2008), synthetic androgens have negative effects on folliculogenesis, but it is not yet clear if these effects are due only to AR or to the conversion of androgen into estrogens, with a potential to exert their actions via $E_{2}-E R$ signaling. We also have to take into consideration that the deleterious effects promoted by the different doses of ND in the ovaries may have changed the mediation of other substances involved in folliculogenesis, such as insulin-like growth 
factor (IGF) (Rosa e Silva et al. 2006) and thyroid hormones (Serakides et al. 2001), which have important functions in the follicular development. Therefore, the action of AAS on follicular development and ovarian regulation still needs more attention, and further studies to elucidate the mechanism(s) involved are required.

The presence of high AR immunostaining in the granulosa and theca cells of antral and atretic follicles of androgenized rats correlates to the ovaries of transsexual patients treated with androgen or even patients with PCOS (Chadha et al. 1994), thus confirming that androgens have a key role in the growth and follicular maturation, atresia and luteinization (Drummond et al. 2002, Walters et al. 2008). The changes in AR expression were more pronounced in the highest dose level, particularly after the ND treatment. In addition, high AR expression in ovaries of animals after 30 and 60 days of recovery indicates that the regulation of AR induced by ND might persist for a considerable period after treatment cessation. This study suggests that the effects of ND were mediated by direct AR activation in ovarian tissue.

$E R-\beta$ is the main form present in the ovaries, and the isoforms ER- $\alpha$ and $-\beta$ are extremely important for the maintenance of fertility and ovarian function (Drummond \& Fuller 2012). As expected, high levels of ER- $\alpha$ and ER- $\beta$ are expressed in the normal ovary (Kuiper et al. 1997); however, in PCOS patients, the ER- $\beta$ expression is reduced in the granulosa and theca cells (Jakimiuk et al. 2002), and in PCOS rodent model, this expression is also reduced in the granulosa of cystic follicles (Zurvarra et al. 2009). The ovaries of ND-treated animals showed high ER- $\beta$ levels in the granulosa cells of antral and atretic follicles and follicular cysts after the ND treatment and 30-day recovery, and they were dose-dependent at 60-day recovery. Notably, the highest dose of $15 \mathrm{mg} \mathrm{ND} / \mathrm{kg}$ had a different pattern of ER- $\beta$ expression. Conversely, the expression of follicular ER- $\alpha$ was independent of dose and recovery period. For example, $15 \mathrm{mgND} / \mathrm{kg}$ dosing level stimulated ER- $\alpha$ expression at 30-day recovery, but a significant decrease in ER- $\alpha$ was observed after 60 days of recovery. We believe that the ovarian dysfunction promoted by ND occurred by altering the expression of ER- $\beta$ and ER- $\alpha$ because the balance of ER/AR ratio in granulosa cells of antral follicles has been broken, and the effect was more evident in animals treated with the highest dose level of ND.

Estrogens are involved in the regulation of ER expression. After ND treatment, the $\mathrm{E}_{2}$ levels increased in animals treated with 7.5 and $15 \mathrm{mg} \mathrm{ND} / \mathrm{kg}$, but remained reduced in all dosing levels after recovery periods. Interestingly, a recent study performed by Elias (2013) showed increased levels of $E_{2}$ in prepubertal female rats treated with stanozolol. Because no responsive effect of $E_{2}$ on the ovarian ER expression was established for ND-treated groups in the post-treatment and postrecovery periods, we suggested that the disruption of $E_{2}$ on the ER- $\alpha$ and ER- $\beta$ ovarian expression is due to a hyperandrogenic environment.
During steroidogenesis, the aromatization process of androgens into estrogens is mediated by the aromatase enzyme. CYP450 is expressed in the corpus luteum and in the peripheral granulosa cells of antral and preovulatory follicles (Stocco 2008). Confirming this report, CYP450 immunostaining ranged from moderate to high in the granulosa cells of antral and atretic follicles and from moderate to low in luteal cells of ND-treated animals. After ND treatment, CYP450 expression was increased in all ND-treated groups, but was decreased after 30 days of recovery, except for the animals treated with $15 \mathrm{mg} \mathrm{ND} / \mathrm{kg}$, and remained decreased after 60 days of recovery. Serum T levels showed a correlation with aromatase expression in ovarian tissue, considering each period. Curiously, women with PCOS have significantly higher follicular testosterone and reduced expression of aromatase in luteinized granulosa cells (Yang et al. 2015). When these cells are isolated from non-PCOS women and treated with $\mathrm{T}(5,15$ and $60 \mathrm{ng} / \mathrm{mL})$, at a similar dose range to that observed in PCOS small follicles, the aromatase expression was significantly decreased in a dose-dependent manner. The authors suggested that the downregulation of aromatase in PCOS may be a result of the hyperandrogenic follicular environment. Our results showed a distinct aromatase expression probably due to the action of exogenous androgen in an in vivo rat model. According to Stocco (2008), FSH is the major stimulating factor of the activity of granulosa cells. In fact, the administration of increasing doses of ND resulted in high serum $\mathrm{T}$ levels, but did not reduce FSH levels after the treatment period. Even after a longer period of recovery, FSH levels remained high, whereas the aromatase and $\mathrm{T}$ levels were reduced in all ND-treated animals. Furthermore, aromatase appeared to be essential to promote elevation in $\mathrm{E}_{2}$ mainly in animals treated with the highest doses of 7.5 and $15 \mathrm{mg} \mathrm{ND} / \mathrm{kg}$.

$\mathrm{T}$ and DHT were higher in androgenized groups, after the post-treatment, and in the highest dose level after 30 days of recovery. Interestingly, the animals had a considerable reduction in the levels of T and DHT after 60-day recovery. It seems that longer period is needed to reduce these hormone levels, which may have longlasting effects in ovarian tissue.

$\mathrm{P}_{4}$ levels varied in a dose- and period-dependent manner, and no correlation was observed between $\mathrm{P}_{4}$ and $E_{2}$ levels because $P_{4}$ is thought to inhibit $E_{2}$ synthesis (Stocco 2008). It is therefore possible that ND has abolished the action of $\mathrm{P}_{4}$ by binding to specific ovarian receptors. Similar findings reported a decrease in $\mathrm{P}_{4}$ levels in rats with DHT- and letrozole-induced PCOS, indicating anovulation and low $\mathrm{P}_{4}$ levels as a result of impaired granulosa cell function (Mannerås et al. 2007, Yang et al. 2015).

Although FSH was unchanged by ND treatment, the LH levels significantly increased with the doses of 3.75, 7.5 and $15 \mathrm{mg} \mathrm{ND} / \mathrm{kg}$ and 30-day recovery was sufficient to restore the normal LH levels. Previous studies have shown 
that AAS alters the production of FSH and $\mathrm{LH}$ by negative feedback on the hypothalamic-pituitary-gonadal axis (Pope \& Katz 1994, Palonek et al. 1995, Gårevik et al. 2011). Bordbar and coworkers (2014) reported that a low dose of ND (3 mg/kg/week) significantly decreased FSH levels in rats and a highest dose $(10 \mathrm{mg} / \mathrm{kg} /$ week $)$ also promoted a reduction in $\mathrm{LH}$ levels. In a model of T-induced PCOS (Tehrani et al. 2014), there was an increase in the LH levels, whereas FSH was unaltered. To better understand the role of ND upon gonadotropins release, future studies focused on serum levels of inhibin, activin and even insulin may be helpful.

We concluded that ND promoted changes in the estrous cycle, as well as in the expression of sex ovarian steroid receptors and sex hormones in a dose- and time-dependent manner. Notably, these changes were restored only at lower doses of ND and after a longer period of recovery. This study also showed that most of the effects due to ND, which are related to hormonereceptor interface in ovarian tissue, are similar to those found in PCOS. Further investigations on different hormones and growth factors are needed to identify other possible regulatory mechanism(s).

\section{Declaration of interest}

The authors declare that there is no conflict of interest that could be perceived as prejudicing the impartiality of the research reported.

\section{Funding}

This work received specific grant from FAPESP - Foundation for Research Support of São Paulo (Grant number 2012/01747-0 and 2013/14510-0) and FUNDUNESP - Foundation for the Development of UNESP (Process number 2178/002/14).

\section{References}

Arlt W 2006 Androgen therapy in women. European Journal of Endocrinology 154 1-11. (doi:10.1530/eje.1.02062)

Badawy A \& Elnashar A 2011 Treatment options for polycystic ovary syndrome. International Journal of Women's Health 3 25-35. (doi:10.2147/ijwh.s11304)

Barton Pai A, Chretien C \& Lau AH 2002 The effects of nandrolone decanoate on nutritional parameters in hemodialysis patients. Clinical Nephrology 58 38-46. (doi:10.5414/CNP58038)

Belardin LB, Simão VA, Leite GAA, Chuffa LGA \& Camargo ICC 2014 Dose-dependent effects and reversibility of the injuries caused by nandrolone decanoate in uterine tissue and fertility of rats. Birth Defects Research Part B: Developmental and Reproductive Toxicology 101 168-177. (doi:10.1002/bdrb.21104)

Bento-Silva MT, Martins MCC, Torres-Leal FL, Barros TL, Carvalho ILNF, Carvalho Filho HA \& Almeida RFG 2010 Effects of administering testosterone undecanoate in rats subjected to physical exercise: effects on the estrous cycle, motor behavior and morphology of the liver and kidney. Brazilian Journal of Pharmaceutical Sciences 46 79-89. (doi:10.1590/S1984-82502010000100009)

Bhasin S, Woodhouse L, Casaburi R, Singh AB, Mac RP, Lee M, Yarasheski KE, Sinha-Hikim I, Dzekov J, Magliano L et al. 2005 Older men are as responsive as young men to the anabolic effects of graded doses of testosterone on the skeletal muscle. Endocrinology and Metabolism 90 678-688. (doi:10.1210/jc.2004-1184)

Bird HA, Burkinshaw L, Pearson D, Atkinson PJ, Leatham PA, Hill J, Raven A \& Wright V 1987 A controlled trial of nandrolone decanoate in the treatment of rheumatoid arthritis in postmenopausal women. Annals of the Rheumatic Diseases 46 237-243. (doi:10.1136/ard.46.3.237)

Blasberg ME, Langan CJ \& Clark AS 1997 The effects of 17 alphamethyltestosterone, methandrostenolone, and nandrolone decanoate on the rat estrous cycle. Physiology \& Behavior 61 265-272. (doi:10.1016/ s0031-9384(96)00409-x)

Boff SR 2010 Esteroides anabólicos e exercício: ação e efeitos colaterais. Revista Brasileira de Ciência e Movimento 18 81-88. (doi:10.18511/01031716/rbcm.v18n1p81-88)

Bordbar H, Mesbah F, Talaei T, Dehghani F \& Mirkhani H 2014 Modulatory effect of gonadotropins on rats' ovaries after nandrolone decanoate administration: a stereological study. Iranian Journal of Medical Sciences 39 44-50.

Bronson FH, Nguyen KQ \& de La Rosa J 1996 Effect of anabolic steroids on behavior and physiological characteristics of female mice. Physiology of Behavior 59 49-55. (doi:10.1016/0031-9384(95)02027-6)

Camargo ICC, Souza RB, Mesquita SFP, Chuffa LGA \& Frei F 2009a Ovarian histology and follicular score in female rats treated with nandrolone dacanoate and submitted to physical effort. Acta Biologica Hungarica 60 253-261. (doi:10.1556/ABiol.60.2009.3.2)

Camargo ICC, Gaspar ALC, Frei F \& Mesquita SFP $2009 b$ Efeitos dos esteroides anabólicos androgênicos sobre o útero e parâmetros reprodutivos de ratas adultas. Revista Brasileira de Ginecologia e Obstetrícia 31 453-460. (doi:10.1590/s0100-72032009000900006)

Camargo ICC, Gênova TC, Machado MCP, Frei F \& Mesquita SFP 2011 Administração experimental de esteróide anabólico androgênico e álcool causa alterações histológicas e morfométricas nos ovários e útero de ratas adultas. Bioscience Journal 27 656-665.

Camargo ICC, Leite GAA, Pinto T \& Ribeiro-Paes JT 2014 Histopathologycal findings in the ovaries and uterus of albino female rats promoted by co-administration of synthetic steroids and nicotine. Experimental Toxicology and Pathology 66 195-202. (doi:10.1016/j.etp.2014.01.005)

Chadha S, Pache TD, Huikeshoven FJM, Brinkmann AO \& Van der Kwast TH 1994 Androgen receptor expression in human ovarian and uterine tissue of long term androgen-treated transsexual women. Human Pathology 25 1198-1204. (doi:10.1016/0046-8177(94)90037-X)

Chuffa LG, Padovani CR \& Martinez FE 2009 Ovarian structure and hormonal status of the UChA and UChB adult rats in response to ethanol. Maturitas 62 21-29. (doi:10.1016/j.maturitas.2008.09.027)

Chuffa LG, Amorim JP, Teixeira GR, Mendes LO, Fioruci BA, Pinheiro PF, Seiva FR, Novelli EL, de Mello Júnior W, Martinez M et al. 2011a Longterm exogenous melatonin treatment modulates overall feed efficiency and protects ovarian tissue against injuries caused by ethanol-induced oxidative stress in adult UChB rats. Alcoholism Clinical Experimental Research 35 1498-1508. (doi:10.1111/j.1530-0277.2011.01486.x)

Chuffa LG, Seiva FR, Favaro WJ, Teixeira GR, Amorim JP, Mendes LO, Fioruci BA, Pinheiro PF, Fernandes AA, Franci JA et al. 2011b Melatonin reduces $\mathrm{LH}, 17$ beta-estradiol and induces differential regulation of sex steroid receptors in reproductive tissues during rat ovulation. Reproductive Biology and Endocrinology 9 108. (doi:10.1186/1477-7827-9-108)

Chuffa LGA, Souza RB, Frei F, Mesquita SFP \& Camargo ICC 2011c Nandrolone decanoate and physical effort: histological and morphometrical assessment in adult rat uterus. Anatomical Record 294 335-342. (doi:10.1002/ar.21314)

Clark AS \& Fast AS 1996 Comparison of the effects of 17 alphamethyltestosterone, methandrostenolone, and nandrolone decanoate on the sexual behavior of castrated male rats. Behavorial Neuroscience 110 1478-1486. (doi:10.1037/0735-7044.110.6.1478)

Clark AS, Costine BA, Jones BL, Kelton-Rehkopf MC, Meerts SH, Nutbrown-Greene LL, Penatti CAA, Porter DM, Yang P \& Henderson LP 2006 Sex-and age-specific effects of anabolic androgenic steroids on reproductive behaviors and on GABAergic transmission in neuroendocrine control regions. Brain Research 1126 122-138. (doi:10.1016/j.brainres.2006.08.081)

Dixon D, Alison R, Bach U, Colman K, Foley GL, Harleman JH, Haworth R, Herbert R, Heuser A, Long G et al. 2014 Nonproliferative and proliferative lesions of the rat and mouse female reproductive system. Journal of Toxicologic Pathology 27 1S-107S. (doi:10.1293/tox.27.1S) 
Drummond AE \& Fuller PJ 2012 Ovarian actions of estrogen receptor- $\beta$ : an update. Seminars in Reproductive Medicine 30 32-38. (doi:10.105 5/s-0031-1299595)

Drummond AE, Britt KL, Dyson M, Jones ME, Kerr JB, O'Donnell L, Simpson ER \& Findlay JK 2002 Ovarian steroid receptors and their role in ovarian function. Molecular and Cellular Endocrinology 191 27-33. (doi:10.1016/S0303-7207(02)00052-7)

Ehrmann DA 2005 Polycystic ovary syndrome. New England Journal of Medicine 352 1223-1236. (doi:10.1056/NEJMra041536)

Elias LS 2013 Efeito do estanozolol sobre a fertilidade em ratas pré-púberes. Programa de Pós-Graduação em Biociência Animal, Universidade Federal do Paraná - UFPR, 62 p.

Evans NA 1997 Gym and tonic: a profile of 100 male steroid users. Brazilian Journal of Sports Medicine 31 54-58. (doi:10.1136/bjsm.31.1.54)

Evans NA 2004 Current conceptions in anabolic-androgenic steroids. American Journal of Sports Medicine 32 534-542. (doi:10.1177/0363546503262202)

Gårevik N, Strahm E, Garle M, Lundmark J, Ståhle L, Ekström L \& Rane A 2011 Long term perturbation of endocrine parameters and cholesterol metabolism after discontinued abuse of anabolic androgenic steroids. Journal of Steroid Biochemistry and Molecular Biology 127 295-300. (doi:10.1016/j.jsbmb.2011.08.005)

Gerez JR, Frei F \& Camargo ICC 2005 Histological assessment of ovaries and uterus of rats subjected to nandrolone decanoate treatment. Contraception 72 77-80. (doi:10.1016/j.contraception. 2005.02.001)

Gervásio CG, Bernuci MP, Silva-de-Sá MF \& Rosa-e-Silva ACJDS 2014 The role of androgen hormones in early follicular development. ISRN Obstetrics and Gynecology 2014 1-11. (doi:10.1155/ 2014/818010)

Geusens P 1995 Nandrolone decanoate: pharmacological properties and therapeutics use in osteoporosis. Clinical Rheumatology 14 32-39. (doi:10.1007/BF02210686)

Goldman JM, Murr AS \& Cooper RL 2007 The rodent estrous cycle: characterization of vaginal cytology and its utility in toxicological studies. Birth Defects Research Part B: Developmental and Reproductive Toxicology 80 84-97. (doi:10.1002/bdrb.20106)

Honnma H, Endo T, Kyia T, Shimizu A, Nagasawa K, Baba T, Fujimoto T, Henmi H, Kitajima Y, Manase K et al. 2010 Remarkable features of ovarian morphology and reproductive hormones in insulin-resistant Zucker fatty (fa/fa) rats. Reproductive Biology and Endocrinology 873. (doi:10.1186/1477-7827-8-73)

Iriart JAB, Chaves JC \& De Orleans RG 2009 Culto ao corpo e uso de anabolizantes entre praticantes de musculação. Cadernos de Saúde Pública 25 773-782. (doi:10.1590/s0102-311x2009000400008)

Jakimiuk AJ, Weitsman SR, Yen HW, Bogusiewicz M \& Magoffin DA 2002 Estrogen receptor alpha and beta expression in theca and granulosa cells from women with polycystic ovary syndrome. Journal of Clinical Endocrinology and Metabolism 87 5532-5538. (doi:10.1210/jc.2002020323)

Karbalay-Doust S \& Noorafshan A 2012 Stereological estimation of ovarian oocyte volume, surface area and number: application on mice treated with nandrolone decanoate. Folia Histochemica et Cytobiologica 50 275-279. (doi:10.5603/FHC.2012.0037)

Kicman AT 2008 Pharmacology of anabolic steroids. British Journal of Pharmacology 154 502-521. (doi:10.1038/bjp.2008.165)

Kuiper GG, Carlsson BO, Grandien KAJ, Enmark E, Haggblad J, Nilsson S \& Gustafsson JA 1997 Comparison of the ligand binding specificity and transcript tissue distribution of estrogen receptors $\alpha$ and $\beta$. Endocrinology 138 863-870. (doi:10.1210/en.138.3.863)

Kuipers H 1998 Anabolic steroids: side effects. In Encyclopedia of Sports Medicine and Science. Ed TD Fahey. Internet Society for Sport Science: www.sportsci.org/encyc/anabstereff/anabstereff.html.

Lima-Verde IB, Rossetto R \& Figueiredo JR 2011 Influência dos hormônios esteroides na foliculogênese. Revista Brasileira de Reprodução Animal 35 472-482. (doi:10.1210/en.138.3.863)

Mannerås L, Cajander S, Holmang A, Seleskovic Z, Lystig T, Lönn M \& Stener-Victorin E 2007 A new rat model exhibiting both ovarian and metabolic characteristics of polycystic ovary syndrome. Endocrinology 148 3781-3791. (doi:10.1210/en.2007-0168)

Maravelias C, Dona A, Stefanidou M \& Spiliopoulou C 2005 Adverse effects of anabolic steroids in athletes - a constant threat. Toxicology Letters 158 167-175. (doi:10.1016/j.toxlet.2005.06.005)
Marcondes FK, Bianchi FJ \& Tanno AP 2002 Determination of the estrous cycle phases of rats: some helpful considerations. Brazilian Journal of Biology 62 609-614. (doi:10.1590/S1519-69842002000400008)

Marqueti RC, Prestes J, Wang CC, Ramos OH, Perez SE, Nakagaki WR, Carvalho HF \& Selistre-Araujo HS 2010 Biomechanical responses of different rat tendons to nandrolone decanoate and load exercise. Scandinavian Journal of Medicine \& Science in Sports 21 91-99. (doi:10.1111/j.1600-0838.2010.01162.x)

Mobini Far HR, Agren G, Lindqvist AS, Marmendal M, Fahlke C \& Thiblin I 2007 Administration of the anabolic androgenic steroid nandrolone decanoate to female rats causes alterations in the morphology of their uterus and a reduction in reproductive capacity. European Journal of Obstetrics \& Gynecology and Reproductive Biology 131 189-197. (doi:10.1016/j.ejogrb.2006.07.037)

Osman P 1985 Rate and course of atresia during follicular development in the adult cyclic rat. Journal of Reproduction and Fertility 73 261-270. (doi:10.1530/jrf.0.0730261)

Palonek E, Gottlieb C, Garle M, Björkhem I \& Carlström K 1995 Serum and urinary markers of exogenous testosterone administration. Journal of Steroid Biochemistry and Molecular Biology 55 121-127. (doi:10.1016/0960-0760(95)00146-Q)

Pedersen T \& Peters H 1968 Proposal for a classification of oocytes and follicles in the mouse ovary. Journal of Reproduction and Fertility $\mathbf{1 7}$ 208-212. (doi:10.1530/jrf.0.0170555)

Pope HG \& Katz DL 1994 Psychiatric and medical effects of anabolicandrogenic steroid use: a controlled study of 160 athletes. Archives of General Psychiatry 51 375-382. (doi:10.1001/ archpsyc.1994.03950050035004)

Rosa e Silva ACJS, Rosa e Silva JC, Gomes MKO, Reis RM, Ferriani RA \& Sá MFS 2006 Aspectos fisiológicos do LH na foliculogênese. Femina 34 469-476.

Serakides R, Nunes VA, Nascimento EF, Ribeiro AF \& Silva CM 2001 Foliculogênese e esteroidogênese ovarianas em ratas adultas hipertireoideas. Arquivo Brasileiro de Endocrinologia e Metabologia 45 258-264. (doi:10.1590/s0004-27302001000300008)

Simão VA, Berloffa Belardin L, Leite GAA, Almeida Chuffa LG \& Camargo ICC 2015 Effects of different doses of nandrolone decanoate on estrous cycle and ovarian tissue of rats after treatment and recovery periods. International Journal of Experimental Pathology 96 338-349. (doi:10.1111/iep.12144)

Stocco C 2008 Aromatase expression in the ovary: hormonal and molecular regulation. Steroids 73 473-487. (doi:10.1016/j.steroids.2008.01.017)

Tehrani FR, Noroozzadeh M, Zahediasl S, Piryaei A \& Azizi F 2014 Introducing a rat model of prenatal androgen-induced polycystic ovary syndrome in adulthood. Experimental Physiology 99 792-801. (doi:10.1113/expphysiol.2014.078055)

Thiblin I \& Petersson A 2004 Pharmacoepidemiology of anabolic androgenic steroids: a review. Fundamental \& Clinical Pharmacology 19 27-44. (doi:10.1111/j.1472-8206.2004.00298.x)

Walters KA, Allan CM \& Handelsman DJ 2008 Androgen actions and the ovary. Biology of Reproduction 78 380-389. (doi:10.1095/ biolreprod.107.064089)

Wang PH \& Chang C 2004 Androgens and ovarian cancers. European Journal of Gynaecology and Oncology 25 157-163.

Wu C, Lin F, Qiu S \& Jiang Z 2014 The characterization of obese polycystic ovary syndrome rat model suitable for exercise intervention. PLOS ONE 9 1-8. (doi:10.1371/journal.pone.0099155)

Yang F, Ruan Y-C, Yang Y-J, Wang K, Liang S-S, Han Y-B, Teng X-M \& Yang J-Z 2015 Follicular hyperandrogenism downregulates aromatase in luteinized granulosa cells in polycystic ovary syndrome women. Reproduction 150 289-296. (doi:10.1530/REP-15-0044)

Zurvarra FM, Salvetti NR, Mason J, Velazquez MM, Alfaro NS \& Ortega HH 2009 Disruption in the expression and immunolocalisation of steroid receptors and steroidogenic enzymes in letrozole-induced polycystic ovaries in rat. Reproduction, Fertility and Development 21 827-839. (doi:10.1071/RD09026)

Received 28 April 2016

First decision 30 May 2016

Revised manuscript received 4 August 2016

Accepted 24 August 2016 